\title{
CEZA YARGILAMASININ GELECEĞİ: ROBOT HAKİM
}

\author{
(Araştırma Makalesi)
}

DOI: https://doi.org/10.33717/deuhfd.998255

\section{Arş. Gör. Seda Yă̆mur SÜMER*}

\begin{abstract}
$\ddot{\mathbf{O} z}$
Robotlar ve yapay zekanın kullanım alanı her geçen gün heyecan verici derecede genişlemekte ve değişmektedir. Başta mühendislik, endüstri, eğitim, sağllk gibi alanlarda heyecan veren bu gelişmeler zaman içerisinde hukuk dünyasında da yer edinmeye başlamış ve birçok önemli tartışmanın doğuşuna zemin hazırlamıştır. Bu tartışmalardan biri de çalışma konusu olan yargılamada robot hakimlerin görev alıp alamayacağl sorunudur. Her ne kadar bu sorun önceden "uzak bir hayal" olarak nitelendirilse de bu konunun günümüzün gerçeği olma yolunda önemli örnekleri bulunmaktadır. Bu nedenle hukukun teknolojik gelişmeleri geriden takip etmemesi adına; şu an mevcut ve ilerleyen zamanda yaygınlaşması muhtemel bir gelişmenin hukuk dünyasındaki olası sonuçlarının olumlu ve olumsuz yönleriyle ele alınmast önem arz etmektedir.
\end{abstract}

\section{Anahtar Kelimeler}

Robotlar, Yapay zeka, Robot hakim, Robot hukuku, Ceza hukuku, Elektronik yargılama, Ceza muhakemesi hukuku

\section{THE FUTURE OF CRIMINAL PROCEEDING: ROBOT JUDGE}

\section{(Research Article)}

\begin{abstract}
The usage of robots and artificial intelligence is expanding and changing every day. These exciting developments, especially in areas such as engineering, industry, education, and health, began to influence the legal world over time and became the ground for many important discussions. One of these debates is the question of whether robot judges can take part in the trial, which also is the

Dokuz Eylül Üniversitesi Hukuk Fakültesi, Ceza ve Ceza Muhakemesi Hukuku Anabilim Dal, İzmir (sedayagmur.sumer@deu.edu.tr), ORCID: 0000-0001-8071-1889 (Geliş Tarihi: 04.07.2021-Kabul Tarihi: 08.09.2021)
\end{abstract}


subject of this study. Although this problem was previously described as a "distant dream", there are important examples of this issue on the way to becoming a reality today. For this reason, it is important to consider the positive and negative aspects of the possible consequences of a development in the legal world that is likely to be widespread now and in the future, in order to ensure that law does not follow technological developments behind.

\section{Keywords}

Robots, Artificial intelligence, Robot judge, Robo-law, Criminal law, Electronic trial, Criminal procedure law 


\section{GİRİŞ}

Günümüzde hukuk alanında yapay zeka kullanımı giderek yaygınlaşmaktadır. Online duruşmaların yapılması, video konferansların gerçekleştirilmesi, telekonferansların yapılması, otomatik belgeleme işlerinin yapılmasını sağlayan otomasyonlar, içtihat bankaları, yargıda kullanılan tahmin teknolojileri gibi birçok alanda yapay zeka uygulamalarının kullanıldığını görmekteyiz. Bu yaygın kullanım teknolojide yaşanan dinamik değişimler nedeniyle giderek gelişmekte ve başkalaşmaktadır. Hal böyle iken bu gelişim spesifik kullanım alanları bakımından ciddi hukuki tartışmaları da beraberinde getirmektedir. Nitekim çalışma konumuz olan "Robot Hakimler" de bu önemli hukuki tartışmaları barındıran alanlardan biridir.

Robot Hakimlerin varlığı karşısında yarg1 organlarının süjeleri; fiziki varlığını, itibar ve yetkilerini korumakta iken, yapay zekanın buradaki işlevi bir alternatif üreterek yargısal süreçleri kolaylaştırarak destekleyici bir vazife görmektir. Bu bakış açısının ötesine geçildiğinde yargı mensuplarının ya da mahkemenin fiziksel varlığı yerine bu varlığı doldurabilecek bir alternatif üretilmesi mümkün müdür? İşte bu soru robot hakim fikrinin ortaya çıkışındaki temel itici güçlerden biridir. Bu fikrin ortaya çıkışı, uygulamadaki örnekleri ve bu fikrin uygulanması halinde doğacak olası sonuçlar bu çalışmanın temel konusunu oluşturmaktadır. Bununla birlikte ifade etmek gerekir ki bu çalışma "Robot Hakimleri" ele alırken odak noktası ceza muhakemesi hukuku olacaktır ve temelde ceza yargılaması özelinde doğabilecek önemli sonuçlara değinilecektir.

$\mathrm{Bu}$ çalışmada öncelikle konunun daha iyi anlaşılabilmesi adına temel kavramlar hakkında bilgi verilecektir. Ardından günümüzde yargı mekanizmasındaki karar verme sürecinin nasıl olduğuna ilişkin bir değerlendirme yapılacaktır. $\mathrm{Bu}$ değerlendirme "insan hakimin" yargıdaki rolü ve karar verme süreçlerinin nasıl gerçekleştiği konusunda bizlere fikir verecektir. Ardından "robot hakimlerin" yargının bir süjesi olması halinde karar verme süreçlerinin nasıl olacağına değinilecektir. Burada insan hakim/robot hakim karar verme süreçlerindeki farklılıkların ortaya konulması önem arz etmektedir. Bu açıklamalar doğrultusunda konuya ilişkin yol gösterici uluslararası belgelere değinilecek ve sonuç olarak verilen bilgiler 1şı̆̆ında "robot hakim" uygulamasının ceza muhakemesi bakımından ne gibi sonuçları olacağı ortaya konulacaktır. 


\section{YAPAY ZEKA VE ROBOT KAVRAMI ${ }^{1}$}

\section{A. Robot Kavramı}

Çalışmanın ilerleyen bölümlerinde yer alan tartışmaların daha iyi anlaşılabilmesi adına öncelikle belirli temel kavramların genel hatlarıyla açıklanmasında fayda vardır. Bu nedenle öncelikle robot kavramından ne anlamamız gerektiğine değinecek olursak; robotlar bazen basit ve tekdüze bazen de çok karmaşık işleri yerine getirmek için tasarlandıkları için robotların tasarımı da üretim amaçlarına göre farklılıklar göstermektedir. Robot esasen fiziksel bir yapı ve o yapının işlemesini sağlayan bir yazılımdan meydana gelmektedir. Tip dünyasında kullanılan nano robotlardan insansız hava araçlarına kadar geniş bir robot tasarım alanından söz etmek mümkündür². Bu geniş yelpaze karşısında robot kavramının doktrinde birçok tanımı bulunmaktadır.

$\mathrm{Bu}$ tanımlardan birkaçına değinecek olursak:

"Fiziksel olarak hareket edebilen, otonom veya yarı otonom bir makine", "Çevrelerinden sensörleri ile veri toplayan, bir algoritmaya dayal olarak hareket eden ve çevresi ile etkileşim içerisinde bulunan makineler", "İster metal ister başka tür aletler yardımı ile şekli bir görünüme sahip olan yapıların herhangi bir program veya elektronik devre (yazllım) yüklenerek kontrol altına alınması ile oluşturulmuş mekanik-yapay özneler " ş̧eklinde tanımlar bulunmaktadır.

ISO $8373^{6}$ ise robotu şu şekilde tanımlıor": "iki veya daha fazla eksende programlanabilen, belirli bir otonomi seviyesine sahip, amaçlanan

1 Bu bölümde temel kavramlara ilişkin yapılan açıklamalar yazarı olduğum "Robotlar, Yapay Zeka ve Ceza Hukuku” adlı eserden alınmıştır. Bakınız: Bacaksız, Pınar/Sümer, Seda Yağmur, Robotlar: Yapay Zeka ve Ceza Hukuku, Adalet Yayınevi, Ankara 2021, s. 17-19, 22-26.

2 Ersoy, Çağlar: Robotlar ve Ceza Hukuku, Onikilevha Yayıncılık, 4. Bası, İstanbul 2019, s. 5.

3 Yüksel, Bozkurt Armağan Ebru: "Robot Hukuku”, Türkiye Adalet Akademisi Dergisi, Cilt:7, Say1:29, 2017, s. 89.

4 Özparlak, Başak Ozan: "İnsan-Robot Etkileşimi ve Hukuk”, Hukuk Köprüsü, Cilt: 16, Say1: 16, 2019, s. 198.

5 Aydemir, Melisa: "Yapay Zekalı Robotların Ceza Sorumluluklarının Araştırılması", Suç ve Ceza Dergisi, Sayı: 4, 2018, s. 5.

6 TK20: Makine Güvenliği Teknik Komitesi hazırlık grubu tarafından 18.02.2016 tarihinde kabul edilen "Robotlar ve robotik aygıtlar- Sözlük" başlıklı gerek sanayi ortamlarında gerekse sanayi dışı ortamlarda kullanılan robotlar ve robotik cihazlarla ilgili terimleri tanımlayan uluslararası standart. 
görevleri yerine getirebilmek için çevresi içinde hareket eden hareketli mekanizmadır"

Daha karmaşık bir başka robot tanımı ise şu şekildedir ${ }^{8}$ :

"Dış dünya ile etkileşime girmesine izin veren bir vücut ile donatılmış veya bir yazllım veya program gibi soyut bir varlığı olan, işlevini yerine getirirken bir insan tarafindan doğrudan kontrol edilen veya gözetim altında bulundurulan veya farkl karmaşıklı seviyelerinde olan ve diş ortama da müdahale etmek de dahil olmak üzere mevcut alternatifler arasindan önceden belirlenmemiş seçimler yapmay içerebilecek (tekrarlayan nitelikte veya tek seferlik) görevlerini yerine getirirken otonom şekilde hareket eden ve kullanıcısı, yaratıcısı veya programcisı tarafindan belirlendiği üzere bir sonuca ulaşmayı veya sonradan değerlendirilmek üzere bilgi sağlamayı hedefleyen ve bu sırada insanlar ile çeşitli şekillerde ve seviyelerde etkileşime girebilen ve işbirliği yapabilen bir makine."

$\mathrm{Bu}$ tanımlar doğrultusunda ifade etmek gerekir ki robotlar üç bileşenden oluşur':

Sensörler: Bunlar robotun çevreyi gözlemlemesini ve algılamasını sağlar.

$>$ İşlemciler: Robotun ne tepki vereceğini belirler.

D Efektörler: Robotun verdiği karar doğrultusunda hareket etmesini sağlar.

Robotun bileşenlerinden sonra bir varlığın robot olabilmesi için taş1ması gereken temel özelliklerin şunlar olduğu söylenebilir ${ }^{10}$ :

Algılama/Hissetme Kabiliyeti: Robotun çevresindeki uyarıcıları algilaması ve bunlara tepki vermesi gerekmektedir. Burada kast edilen çevrenini algılanması elbette insanların çevrelerini algılamaları gibi değildir. Robota eklenen bazı sensörler ile bu sağlanabilecektir. Işık sensörleri (gözler), dokunma ve basınç sensörleri (eller), kimyasal sensörler (burun), işitme ve sonar sensörleri (kulaklar) ve tat sensörleri (dil) olarak düşünülmelidir.

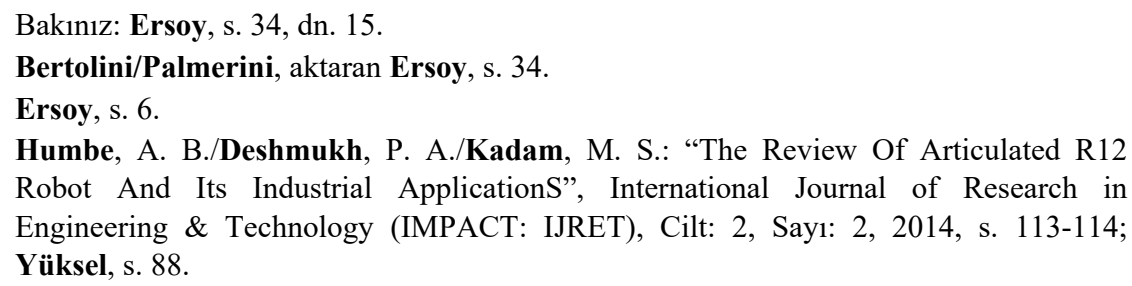


Hareket Kabiliyeti: Robotun kismen veyahut tamamen hareket kabiliyetinin bulunması gerekmektedir. Robotun tekerlekler üzerinde kayarak hareket etmesi ya da yürüyerek hareket etmesi önem arz etmez. Örneğin; bir robotun sadece kolları hareket edebileceği gibi bütün vücuda da hareket edebilir.

Enerji: Robot elektrik, güneş enerjisi, pil veyahut başka bir enerji kaynağına sahip olmalıdır.

> Zeka: Robotun bir zekaya sahip olması gerekmektedir. Burada robotun programcıları devreye girmektedir. Çünkü programcı, robota 'zekasını' veren kişidir. Burada bahsedilen zeka mutlaka yapay zeka düzeyinde olmak zorunda değildir.

\section{B. Yapay Zeka-Makine Öğrenmesi-Derin Öğrenme Kavramları}

İnsan beyni yüzy1llar boyunca en komplike ve eşsiz makine olarak tarihte yer edinmiştir. Bu eşsizlik birçok soru işaretini ve bilimsel çalışmayı da beraberinde getirmiştir. Buna rağmen insan beyninin yapısıyla ilgili halen aydınlatılamamış birçok karanlık alan bulunmaktadır. Günümüzde bu mükemmel yapıdan ilham alınarak insan beyniyle rekabet edebilecek icatlar yapılması hedeflenmektedir. Bu hedef doğrultusunda ise; bilgisayarların icat edilmesiyle insan beyniyle yarışabilecek düzeyde hesaplama yapabilen ve problem çözebilen bir mekanizmanın mümkün olabileceği gibi bir sonuca varılmıştır. Fakat bu sonucun başlı başına insan beyni ile olan yarışta galibiyet sağlayamadığı yapılan deney ve gözlemler neticesinde elde edilmiştir. Çünkü insan beyni çevresini algılamakta, mevcut olasılıklar karşısında tecrübeleri ve sezileriyle karar almakta ve kendi hareketlerini kontrol edebilmektedir. Temelde bu özelliklerden ilham alarak yapay zeka kavramının doğduğunu ifade etmek yerinde olacaktır.

"Yapay zeka" kavramı en yaygin kullanılan kavram olsa da doktrinde bazı yazarlar "yaratılmış zeka(created intelligence)" kavramını da kullanmaktadırlar ${ }^{11}$. Bu açıklamalar doğrultusunda doktrinde yapay zeka kavramının birçok tanımının bulunduğunu ifade etmek yerinde olacaktır.

Yapay zeka; "Insan zekası ile gerçekleştirilen düşünme, anlama, kavrama, yorumlama ve ögrenme işlemlerini bilgisayar programları aracıll-

11 Williams, Damien P.: "Strange Things Happen at the One Two Point: The Implications of Autonomous Created Intelligence in Speculative Fiction Media, The Machine Question: AI, Ethics and Moral Responsibility", AISB/IACAP WORLD CONGRESS 2012, Birmingham, UK, 2-6 July 2012, s. 97. 
ğıyla problem çözümüne uygulanması" ${ }^{12}$ olarak tanımlanabilir. Aslında bir başka ifade ile programlanmış olan bir bilgisayara düşünebilme yetisinin kazandırılabilmesidir. Bir başka tanıma göre yapay zeka; makinelere zeka kazandırmaya adanmış etkinlik anlamına gelmektedir ${ }^{13}$.

Yine yapay zeka; "tamamen yapay yollarla oluşturulmuş, herhangi bir canlı organizma olmaksızın insan gibi davranışlar sergileyebilen yapılar ${ }^{14 \text { “, }}$ "makineler kullanarak insan yahut hayvan bilişinin bazı yönlerini taklit etmeye yönelik bir dizi teknikler bütünü"15, "Yapay zeka, insan davranışlarına özgü karakteristik özellikleri sergileyen akıllı sistemlerle ilgilenen, bilgisayar biliminin bir dall"16, "bir bilgisayarn ya da bilgisayar denetimli bir makinenin genellikle insana özgü nitelikler olduğu varsayllan akıl yürütme, anlam çıkartma, genelleme ve geçmiş deneyimlerden öğrenme gibi yüksek zihinsel süreçlere ilişkin görevleri yerine getirme yeteneği", "17, "genel olarak insan benzeri bir zekânın simülasyonu", "insanın düşünsel yeteneklerine sahip bir insan yapımı makine $" 19$ olarak ta tanımlanmaktadır.

$\mathrm{Bu}$ tanımlar doğrultusunda ifade etmek gerekir ki yapay zeka ile insan beyni arasında temelde bazı farkl11ıklar bulunmaktadır. İnsan beyni duyguları sezgiler ve ruhsal koşullardan etkilenmektedir. Fakat yapay zeka bak1mından böylesi faktörler söz konusu olmayıp temelde insan beynindeki sinir hücrelerinin yapılarındaki aktarımlar ile benzer hızlı matematiksel temelli

12 Aydemir, Emrah: Weka ile Yapay Zeka, Seçkin Yayıncılık, Güncellenmiş 2. Bask1, Ankara 2019, s. 28.

13 Nilsson, Nils J.: Yapay Zeka Geçmişi ve Geleceği, 2. Baskı, Boğaziçi Üniversitesi Yayınevi, İstanbul 2019, s. 13.

14 Mijwill, Maad M.: "History of Artificial Intelligence", Nisan 2015, s. 3, https://www. researchgate. net/publication/322234922_History_of_Artificial_Intelligence, (E.T: 05.04.2021).

15 Calo, Ryan: "Artificial intelligence policy: a primer and roadmap", Univercity of Bologna Law Review, Cilt: 3, Sayı: 2, 2018, s. 184, https://bolognalawreview.unibo.it/ article/view/8670/8420, (E.T:13.06.2021).

16 Lashbrooke, E. C. (1988): "Legal Reasoning and Artificial İntelligence", 34 Loy. L. Rev. 287, s. 295; Nakleden: Kılıçarslan, Kara Seda: "Yapay Zekanın Hukuki Statüsü ve Hukuki Kişiliği Üzerine Tartışmalar”, Yıldırım Beyazıt Hukuk Dergisi, Yıl: 2019/20, Sayı:4, s. 366.

17 Karaduman, Tevfik: "Yapay Zeka Uygulama Alanları", Gazi Üniversitesi, Bilişim Enstitüsü, Adli Bilişim. A.B.D., s.2, https://www.academia.edu/16703256/Yapay_zeka_ makale_09_06, (E.T:13.06.2021).

18 Zeytin, Zafer/Gençay, Eray: "Hukuk ve Yapay Zekâ: E-kişi, Mali Sorumluluk ve Bir Hukuk Uygulaması”, Türk Alman Üniversitesi Hukuk Fakültesi Dergisi, Cilt: 1, Sayı: 1, 2019, s. 42.

19 Yüksel, s. 89. 
hesaplamalar yapabilme yetisi bulunmaktadır. Oysa insan beyni bu hesaplama yönteminden farklı olarak matematiksel bir metod değil de problemlerin analiz edilmesi ve çözümlenmesi odaklı bir metod izlemektedir ${ }^{20}$. Aslında bu metodsal farkı anlamak adına yapay zekanın bir alt dalı olarak nitelendirilebilecek "makine ögrenmesi” kavramına değinmek gerekir.

Günümüzde veri madenciliğinin bir getirisi olarak hayatımızın birçok alanında ihtiyaç fazlası veriler depolanmaktadır. Buradaki temel amaç aslında makine öğrenmesinin geliştirilebilmesi adına ilgili olabilecek her türlü verinin sistemde bulundurulmasıdır. Makine öğrenmesi; milyonlarca veri yığını içerisinde sürekli analiz yaparak ilgili veri örüntüsünün aslında tespit edilebilmesidir. $\mathrm{Bu}$ örüntü temelde tahminlere dayanmakta olup ileride geleceğe dair olasılıkları hesaplamaktadır. Bu örüntülerin tespit edilerek veri yığını üzerinde uygulanmasını sağlayan yöntemlere genel olarak "makine ögrenmesi (machine learning)" adı verilmektedir. Örneğin; kamera kayıt sistemlerinde bilgisayar tabanlı kaydedilen bütün görüntüler üzerinde analiz yaparak benzer örüntüler tespit edilmektedir. Bu benzer örüntülerden ayrık farklı bir görselin tespiti halinde uyarı sistemleri devreye girmektedir ${ }^{21}$.

Bu kavram aslında yapay zeka kavramı altında yer alan bir tekniği ifade etmektedir. Her ne kadar sıklıkla makine öğrenmesi terimi yapay zeka terimi ile aynı anlamda kullanılsa da bu kavram yapay zeka kavramını açıklamak için tek başına yeterli olmayacaktır.

Makine öğrenmesi kavramından sonra yapay zeka kavramının daha iyi anlaşılabilmesi adına kısaca "derin ögrenme (deep learning)" kavramına değinmek gerekir. İnsan beyninde nöronlar arasında iletişimi yani aslında veri alışverişini sağlayan sinir ağları bulunmaktadır. Bu sinir ağlarına benzer yapılar yapay zeka bakımından da söz konusudur. Bu yapılara genel olarak "yapay sinir ăglarl" adı verilmektedir. Yapay sinir ağları; "insan beyninin en temel özelliği olan öğrenme fonksiyonunu gerçekleştirmeye yarayan bilgisayar sistemleridir" ${ }^{22}$. Bu yapılar insan nöronlarına hem yapısal hem de şekilsel anlamda benzemektedirler ${ }^{23}$. Yapay sinir ağları, insan beyninin öğrenme metodunu taklit ederek elde ettiği verilerden yeni verilerin üretilebilmesini ve yapay zeka sistemlerinin çalışabilmesini sağlayan alt yapı niteliğindeki yazılımlardır.

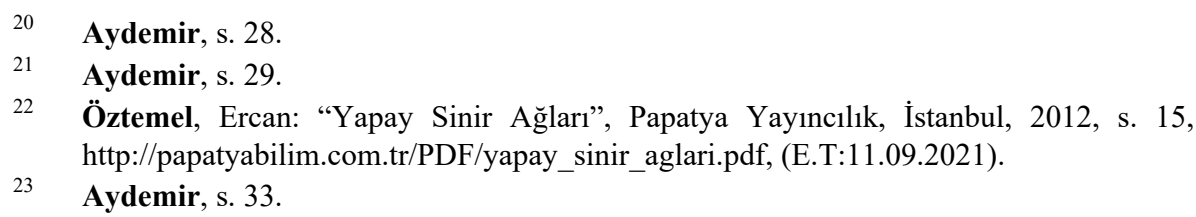


Yapay zekanın keşfedildiği ilk zamanlarda yapay sinir ağı uygulamaları yetersiz kalmakta ve problem çözebilme kabiliyetini olumsuz etkilemekteydi. Gelişen teknolojiyle birlikte yapay sinir ağlarının geliştirilmesi neticesinde problem çözebilme kabiliyetinin arttırılabilmesi adına ideal sinir ağları ve bu sinir ağları bünyesinde ideal sinir sayıları oluşturulmuştur. İşte bu ihtiyacı tespit ederek kendi kendine gerekli yapay sinir ağ 1 ve sinir hücresi sayısını tespit edebilen sistemlere "derin ögrenme" adı verilmektedir ${ }^{24}$. Bir başka deyişle derin öğrenme: "nesne tanıma, konuşma tanıma, doğal dil işleme gibi alanlarda çok katmanlı yapay sinir ağlarını kullanan bir yapay zeka yöntemi olup makine öğrenmesinin çeşitlerinden biridir. "25

$\mathrm{Bu}$ açıklamaları bütüncül bir şekilde toparlayacak olursak yapay zeka kavramı aslında makine öğrenmesi ve derin öğrenme kavramlarını da içine alan bir üst kavram niteliği taşımaktadır.

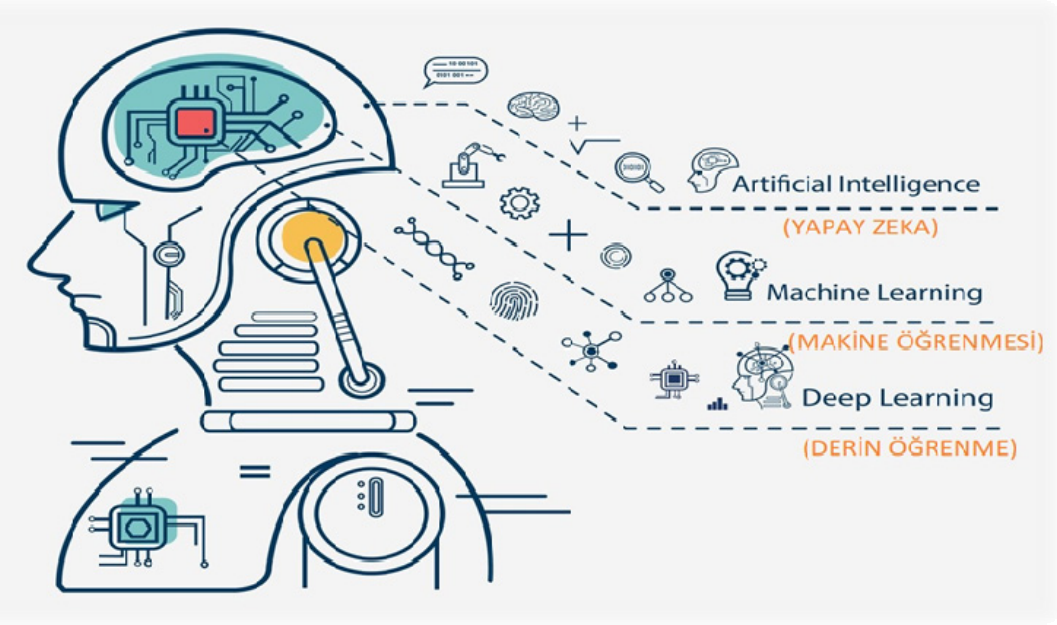

$$
\text { -Şekil } 1-^{26}
$$

Günümüzde yapay zeka çok ciddi ilerleme kat etmiştir. Fakat yapay zekanın; insanın düşünerek yaptığı işleri başarabildiği fakat düşünmeden yaptığı hareketleri yapamadığ 1 görülmektedir. Bunun en önemli örneğini ise dil becerilerine ilişkin konular oluşturmaktadır. Bir insan gibi anlayan ve

\footnotetext{
24 Aydemir, s. 30.

25 Yılmaz, Atınç/Kaya, Umut: Derin Öğrenme, 3. Baskı, KODLAB Yayın Dağıtım, Ocak 2021, s. 1 .

26 https://stratejico.com/yapay-zeka-kavrami-ve-makine-ogrenme-uygulamalari, (E.T:07.05.2021).
} 
cevap verebilen bir yapay zekaya ulaşmak için insanlığın henüz yolu var ${ }^{27}$. Öte yandan bu konularda çalışan pek çok kişi insanlığın teknolojideki ilerleme hızını tartışırken Moore Yasası'na atıf yapar. Moore yasası'na göre; entegre devrelerdeki transistör sayısısın yirmi-otuz yıldır iki yılda bir ikiye katlanır $^{28}$. Dolayısıyla belki de insan beynine yakın formda bir yapay zekaya ulaşmak o kadar da uzun sürmeyebilir.

\section{YARGIDA KARAR VERME MEKANIZMASI}

Tarihsel süreç içerisinde uzun zamandır hukukun ve adil kararların kesinlik, öngörülebilirlik, rasyonellik, tutarlılık, homojenlik gibi temel özelliklere sahip olduğu ileri sürülmektedir. Bir hukukçunun karar verme sürecinde sahip olduğu doğal unsurun genel olarak sağduyu olduğu varsayılsa dahi sağduyunun karar verme sürecindeki tek önemli etken olduğunu düşünmek isabetsiz olacaktır ${ }^{29}$. Çünkü hakimin karar verme süreci içerisinde aşağıda değinileceği üzere birçok değişken ve bu değişkenler arasında karmaşık bağlantılar bulunmaktadır.

Bu noktada yukarıda kavramlar bölümünde izah edildiği üzere insan beyninin makineleştirilmesinin sağlanması için önce insan beyninin tam olarak anlaşlabilir hale gelmesi gerekmektedir. İşte bu noktada robot hakimin karar verme süreçlerinin başarıyla gerçekleşebilmesi için insan hakimin karar verme süreçlerindeki etkenlerin ve işleyişin tam olarak anlamlandırılabilmesi gerekmektedir.

Nitekim tarihsel süreç boyunca filozoflar insan beyninin birçok açıdan makine ile karşılaştırabileceğini ileri sürmüşlerdir. Bu fikir bizi doğru düşünmenin yollarının kodlanabileceği fikrini ortaya atan Aristoteles'e kadar götürmektedir. Ayrıca bilişsel psikologlar insanların ve hayvanların bilgi işleme makineleri olarak düşünülebileceğini ifade etmişlerdir ${ }^{30}$. İşte bu hedef beraberinde insanların yasalar önündeki eşitlik ve özgürlüğünü içeren takdir hakkının "mekanik" yoruma kapalı kurallar ile yer değiştirmesi ihtiyacını doğurmaktadır.

Kısaca düzensizlikten öngörülebilirliğe geçiş yapabilmek için duygularından arınmış bir karar verici modelinin ve bilişsel öznelliğin hedeflen-

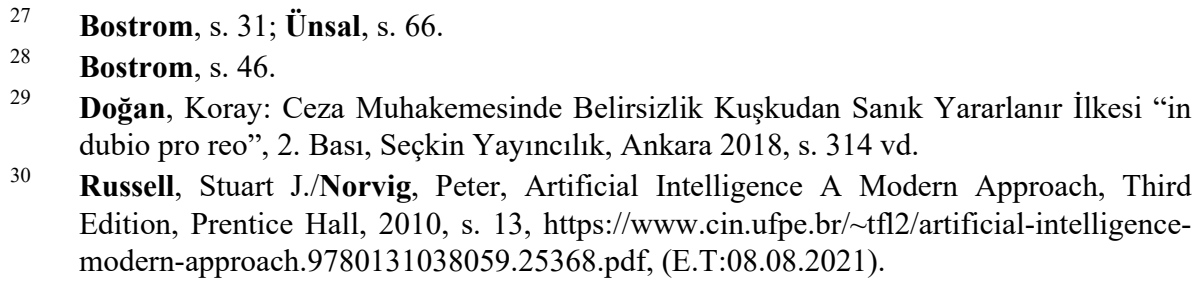


mesi gerekmektedir. Çünkü karar verme fikri aslında kuralların mekanik bir uygulaması niteliğindedir ${ }^{31}$.

$\mathrm{Bu}$ süreçte hakimlerin karar verme mekanizmaları ile ilgili çeşitli görüşler ileri sürülmektedir. Bu görüsslerden biri olan rasyonellere göre; yasal dayanakların rasyonel bir şekilde uygulanması yargı kararlarını açıklamak, gerekçelendirmek hususunda yetersiz kalmaktadır. Çünkü verilen kararları psikolojik, politik ve sosyal faktörler de etkilemektedir ${ }^{32}$.

Nitekim yapılan bir bilimsel çalışmada hakimlerin açlık ve yorgunluk seviyelerinin lehe-aleyhe karar vermek bakımından önemli bir etken olduğu tespit edilmiştir. Çalışmada İsrail'de sekiz hakimin 10 aylık bir süre içinde verdiği 1000'den fazla şartlı tahliye kararı incelenmiştir. Hakimler günde 14 ile 35 arası şartlı tahliye duruşmasına katılmışlardır. Bu duruşmalar üç ayrı oturuma bölünerek değerlendirilmiştir. İlk oturum günün başından ara molaya kadar, ikincisi ara moladan öğle yemeğine kadar ve üçüncüsü öğle yemeğinden gün sonuna kadar sürmüştür ${ }^{33}$.

Çalışmadan elde edilen veriler neticesinde genel olarak hakimlerin; mahkumların şartlı tahliye taleplerini günün başında kabul etme olasılıklarının, günün sonuna göre daha yüksek olduğu; bir mahkumun şartlı tahliye edilme olasılığının, oturumun ilerleyen bölümlerinde değil de üç oturumdan birinin başında dinlenirse iki katından fazla arttığı, hakimlerin oturumda geçirdikleri süreden ziyade verdikleri karar sayılarının sonraki kararlarda da etkili olduğu tespit edilmiştir. Genel olarak hakimler yemek sonrası molanın ardından lehe kararlar verirken açlık ve yorgunluk seviyelerinin arttığı durumlarda aleyhe karar verme eğilimleri artığ 1 sonucuna varılmıştı ${ }^{34 .}$ Görülmektedir ki robot hakim insan hakimden farklı olarak; açlık, uykusuzluk, yorgunluk gibi olgulardan etkilenmeksizin karar verme yetisine sahiptir ${ }^{35}$.

31 Perrone, Francesco: "The Judge of the Future: Artificial Intelligence and Justice", Judicial Ethics and Professional Conduct, Team Italy 2, Semifinal D,Themis 2019, s. 23, https://www.ejtn.eu/PageFiles/17916/TEAM\%20ITALY\%20II\%20TH\%202019\% 20D.pdf, (E.T:11.09.2021).

32 Perrone, s. 6-7.

33 Danziger, Shai/Levav, Jonathan/Avnaim-Pesso, Liora: "Extraneous factors in judicial decisions", www.pnas.org/cgi/doi/10.1073/pnas.1018033108, (Е.T:04.04.2021); To Get Parole, Have Your Case Heard Right After Lunch | WIRED, (E.T:07.05.2021).

34 Danziger/Levav/Avnaim-Pesso, www.pnas.org/cgi/doi/10.1073/pnas.1018033108, (E.T:04.04.2021); To Get Parole, Have Your Case Heard Right After Lunch | WIRED, (E.T:07.05.2021).

35 Reiling, A.D. (Dory): "Courts and Artificial Intelligence", International Journal for Court Administration, 11(2), 2020, s. 3, http://doi.org/10.36745/ijca.343, (E.T:07.05.2021). 
Oysa uygulamada da görüldüğü üzere insan hakimin karar verme sürecinde psikolojisi, değer yargıları, ön yargıları etkili olup insan hakimin karar verme süreci sadece mantıksal değil seziş, hisler ve iradenin de dahil olduğu karmaşık bir süreçtir ${ }^{36}$.

Yapılan bu araştırma akıllara Ponzo yanılsamasını getirir. Ponzo yanılsaması, ilk olarak 1911 tarihinde İtalyan psikolog Mario Ponzo tarafindan ortaya konulmuş geometrik-optik bir yanılsamadır. Ponzo insan zihninin bir nesnenin büyüklüğünü arka planına göre yargıladığı fikrini ortaya atmıştır ${ }^{37}$.

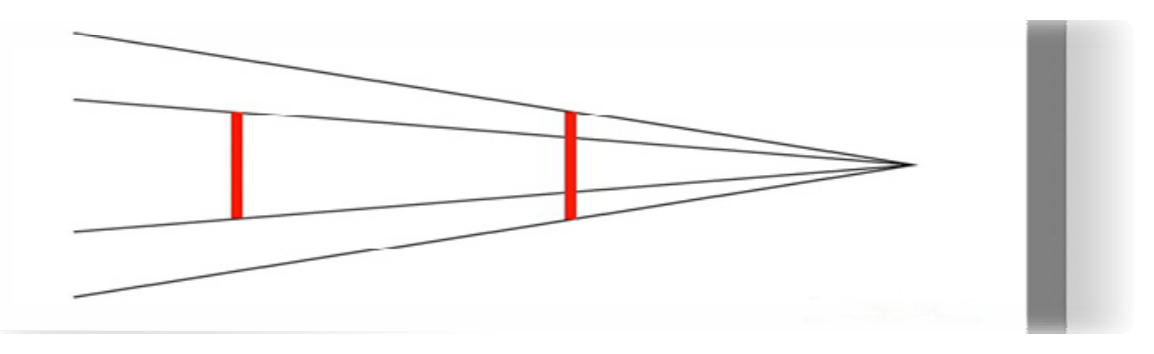

Şekildeki yatay kalın çizgiler aynı büyüklükte olmasına rağmen arkadaki kalın yatay çizgi algı nedeniyle daha uzun görülmesine neden olmaktadır. Bunun nedeni insan beyninin arkadaki kalın yatay çizgiyi uzakta alg1laması ve bu uzaklığı gidermek için çizgiye biraz daha büyük yorumlama$\operatorname{sıdır}^{38}$. Görülmektedir ki insan algısı zihin mekanizmasının çarpıklığı nedeniyle yanılgıya düşmeye müsait bir yapıya sahiptir.

Ortaya konulan bu görüşler akıllara insan zihninin çarpıklığının ve dış etkenlerden bu denli etkilenmesinin karar verme süreçlerinde etkili olup olmadığı sorusunu getirmektedir. Uygulamaya bakıldığında aynı olay veya olgularda hakimlerin bazen farklı kararlar verebildiği görülmektedir. İşte bu noktada bizim sahip olduğumuz bilinçsiz önyargılarımı, bilinçsiz sempatilerimiz, tarafların temsil edilme yetkinliği, bireysel eğilimlerimiz veyahut sunulan kaynaklar, iş yükü, ruhsak durumumuz gibi birçok değişkenin etkili olduğunu görmekteyiz. Nitekim hakimin ne zaman yemek yediği, kararı günün hangi saatinde verdiği, gün içerisinde verdiği karar sayısı, sezgilerine olan güveni, taraf bireylerinin çekiciliği gibi etkenlerin de karar verme sürecinde rol oynadığg ifade edilmektedir. Çünkü insan doğası gereği olumlu özellikleri hakkında onu şüpheye düşürecek hususları reddetme eğilimi içe-

\footnotetext{
Doğan, s. 314 vd.

https://tr.wikipedia.org/wiki/Ponzo_yan\%C4\%B1lsamas\%C4\%B1, (E.T:07.05.2021).

Perrone, s. 7.
} 
risindedir. Bu nedenle bir hakim bireysel özelliklerine ilişkin kuşku yaratan hususları göz ardı etme eğilimiyle karar verebilmektedir ${ }^{39}$.

$\mathrm{Bu}$ sorunun yanıtlanabilmesi için insan aklının nasıl düşündüğünü ve nedenlerini özellikle de hakimlerin karar alma süreçlerinde nasıl düşündügünü ve bu düşüncelerin gerekçelerine odaklanmak gerekmektedir. Bu nedenle başta felsefe, mantık ve psikoloji olmak üzere birçok farklı bilim dalında ortaya atılmış görüşlerden yararlanmak gerekir.

Bu noktada öncelikle Aristoteles’ten başlayan akıl yürütmeye ilişkin temel analizlere değinmek gerekir. Bu analizler genelde akı1 yürütmeye ilişkin üç temel çıkarım üzerinden ilerler: bunlar tümdengelim, tümevarım ve geriçıkarım akıl yürütmedir ${ }^{40}$.

İlk defa Aristoteles tarafindan (M.Ö. 384-322) formüle edilen Tümdengelim ak1l yürütme metodu; genellikle "akll yürütme yoluyla bir sonucun elde edilmesi" olarak tanımlanmaktadır ${ }^{41}$. Tümdengelimli akıl yürütme; her zaman zorunlu olarak genel veya evrensel öncülleri takip etmektedir. Gündelik hayatta sıklıkla kullandığımız bu akıl yürütme yöntemine örnek verecek olursak; bir yere yetişmek istiyor ve belirli bir randevu saatimiz var ise yolda geçecek süreyi hesaplayarak evden çıkmamız gereken zaman dilimini bulmamı tümdengelim yöntemine örnek olarak gösterilebilir.

\section{Tümdengelimsel akıl yürütme $=$ Kural + Açıklama ---> Gözlem ${ }^{42}$. \\ Tüm A'lar B'dir. X bir A'dır. O halde, X bir B'dir' ${ }^{43}$.}

Tümevarım yöntemi ise genel olarak; "belirli örneklerden genelleştirilmiş bir sonucun çıkarılması" şeklinde tanımlanabilir. Burada bilinene veya gözlemlenene dayalı bir genelleme yapılmaktadır. Örneğin; öğle yemeğinde 6 iş arkadaşınızdan 4'ünün aynı sandviçi sipariş ettiğini gözlemlediğimiz bir durumda muhtemelen sandviçin iyi olduğunu düşünüyor ve ken-

Sourdin/Cornes, s. 95-96.

40 Çiçekdağı, Caner: "Aristoteles'te Mantık Kavramı ve Temel Akıl Yürütme Çeşitleri”, MSKU Eğitim Fakültesi Dergisi, Cilt:3, Sayı Nisan 2016, s. 59, https://www.researchgate.net/profile/Caner-Cicekdagi-2/publication/304528109_ Aristoteles'te_Mantik_Kavrami_ve_Temel_Akil_Yurutme_Cesitleri/links/5ef3330f4585 $153 \mathrm{fb} 1 \mathrm{~b} 0 \mathrm{abff} /$ Aristoteleste-Mantik-Kavrami-ve-Temel-Akil-Yueruetme-Cesitleri.pdf, (E.T:11.09.2021).

41 Çüçen, A. Kadir: Mantık, 8. Baskı, Sentez Yayıncılık, Bursa, 2012, s. 17.

42 Tarımcıoğlu, Halise: "Akıl Yürütme Yöntemleri ve Yapay Zekâ”, IX. Mantık Çalıştayı Kitabı, Mantık Derneği Yayınları, İstanbul 2019, s. 426, https://mantik.org.tr/wpcontent/uploads/2019/12/IX-Mantik-Calistayi-Kitabi.pdf, (E.T:07.05.2021).

43 Özlem, Doğan: Mantık, 14. Bas1, Notos Kitap Yayınevi, İstanbul, 2011, s. 39. 
dimiz denemeye karar veriyor isek burada tümevarım yönteminden faydalanmaktayı.

$$
\begin{aligned}
& \text { Tümevarımsal akıl yürütme = Açıklama + Gözlem ---> Kural }{ }^{44} . \\
& \text { "Geçmiş günlerin hepsinde güneş doğudan doğdu.", "Yarın da bir } \\
& \text { gündür." O halde "Yarın da güneş doğudan doğacaktır."45 }
\end{aligned}
$$

Geriçıkarımlı akıl yürütme ise genel olarak "ana önermenin açı olduğu, ancak küçük önermenin ve dolayısıyla sonucun yalnızca olası olduğu bir klyaslama yöntemi" şeklinde tanımlanabilir. Temel olarak, bilinen bilgilerden bir sonuç çıkarmayı içermektedir. Örnek olarak; bir dedektifin suç mahallindeki kanıtları bir araya getirerek bir suçluyu tanımlaması eylemi verilebilir.

\section{Geriçıkarımsal akıl yürütme $=$ Kural + Gözlem ---> Açıklama ${ }^{46}$.}

Akıl yürütme yöntemlerine dair yapılan bu genel açıklamalar hem insan hakimin düşünme ve karar alma sürecini anlamlandırmak hem de makine öğrenmesinde/derin öğrenmede çıtıların elde ediliş sürecini bir başka deyişle robot hakimin karar verme sürecini anlamak için önemlidir. İnsanın akıl yürütme süreçlerine hakim olan bu temel üç akıl yürütme yöntemi yapay zekanın tarihsel gelişimi sürecinde de kendine yer bulmuştur. Çünkü yapay zekâ sistemlerinde kullanılan "zekâ" kavramı da genellikle bir akıl yürütme faaliyetini ifade etmek için kullanılmaktadır ${ }^{47}$.

Tarihsel süreç içerisinde ilk zamanlarda sadece tümdengelimsel yapay zekâ sistemleri söz konusuyken, ilerleyen dönemlerde hem tümevarımsal hem de geriçıkarımsal akıl yürütme yöntemlerine dayalı sistemler geliştirildiği gözlenmektedir. Günümüzde makine öğrenmesi merkezine ağırlıklı olarak tümevarımı alırken, geriçıkarımsal akıl yürütme ise daha çok belirli problemleri çözmek için ek bir teknik ve araştırmaya yol gösterme için kullanılmaktadır. Bununla birlikte geriçıkarım ve tümevarım akıl yürütme yön-

44 Tarımcıŏ̆lu, s. 426.

45 Şen, Zekai: Modern Mantık, Bilge Kültür Sanat, İstanbul 2003, s. 27.

46 https://www.merriam-webster.com/words-at-play/deduction-vs-induction-vsabduction\#: :text='Abduction'\&text=Deductive $\% 20$ reasoning $\% 2 \mathrm{C} \% 20$ or $\% 20$ deduction $\% 2 \mathrm{C} \% 20$ is,widely $\% 20$ accepted $\% 20$ facts $\% 20$ or $\% 20$ premises.\&text=Inductive $\% 20$ reaso ning $\% 2 \mathrm{C} \% 20$ or $\% 20$ induction $\% 2 \mathrm{C} \% 20$ is,of $\% 20$ your $\% 20$ friends $\% 20$ consuming $\% 20$ it., (E.T:04.04.2021).

47 Tarımcıoğlu, s. 425. 
temlerinin makine öğrenmesindeki amaçları; bir problemin tanımında eksik bilgiyi ele almak için bir yöntem sağlamaktır ${ }^{48}$.

Akıl yürütme yöntemlerine ilişkin tüm açıklamalar doğrultusunda görülmektedir ki; gerek hukuk hakimleri gerek ceza hakimleri somut olayın ispatı için varsayımları (karineleri) ve delilleri kullanarak mevcut bilgiler dışında bir karineye dayanan çıkarım yapma yöntemine başvurmaktadırlar. Hukuki gerekçelendirme modeli tarihsel doğası itibariyle de aslında çıkarım yapmayı içermektedir. Zira maddi gerçeğin değerlendirilmesi geriye dönük bir şekilde yapılır. Hakimler ayrıca daha nötr bir şekilde akıl yürütmeye yardımcı olan "deneyim"den de yararlanırlar.

Akı1 yürütme yöntemlerinden yaygın olarak çıkarım yapmadan yararlanılmakla birlikte; bu süreç içerisinde hakimlerin tümdengelimli akıl yürütmeden faydalanmaları mümkün müdür? Bu olasılığın mümkün olması için öncelikle kanun koyucunun yargılama süreci ile ilgili genel ilkeler belirlemesi gerekmektedir. Ancak bu şekilde ara hukuk kurullarına ana hukuk kurulları kullanılarak ulaşılabilecektir. Bu şekilde bir yaklaşım her ne kadar insan hakimin karar alma süreçlerini mekanikleştirmeyi kolaylaştıracak olsa da bir nevi ütopik bir görüştür. Çünkü hakimler yargılama sürecinde akıl yürütürken tümdengelim mantığının şemalarını takip etmezler. Çoğu zaman, hukuk kurallarının uygulanması hakimlerin tümdengelimli akıl yürütmeden daha karmaşık bir zihinsel aktivitesini gerektirir. Delilleri değerlendirmek veya karar vermek zorunda kaldıkları anlarda olduğu gibi daha fazla seçenek arasında bir seçim yapmak zorundadırlar. Nitekim uygulamada verilen kararlara baktığımızda hakimler; farklı temel hak ve özgürlükler arasında bir denge kurmaya çalışmakla birlikte bu dengeyi mükemmel bir şekilde sağlamaları mümkün olmamaktadır. Çünkü hakimlerin somut olaya ilişkin çok fazla faktörü değerlendirmesi zorunda olup verilen gerekçeli kararların özellikle ispat noktasında mantığa dayanması gerekmektedir ${ }^{49}$.

Mantık biliminin bize sunduğu yol gösterici gerekçeler doğrultusunda bilişsel psikoloji savunucularının muhakeme sürecini anlamlandırmak hususundaki fikirleri de bizler için yol göstericidir. Bilişsel psikologların çoğu, muhakemenin iki ayrı bilişsel sistemden destek aldığını belirtmektedirler. Bunlar birbirlerine bağlı olan sezgisel sistem ve analitik sistemdir. İlki insanların ve hayvanların paylaştığı evrensel bir biliş şekli iken; ikincisi sadece insanlar tarafindan kullanılan ve içgüdüsel olmayan ancak yavaş ve kontrollü

48 Tarımcıoğlu, s. 423,428.

49 Perrone, s. 9-10; Doğan, s. 319. 
bir işlem ile karakterize olan ve kurallara dayanan bir sistemdir. İşte bu iki sistem hakimlerin karar verme süreçlerinde akıl yürütmelerinde yardımcı olmaktadır ${ }^{50}$.

Tüm bu süreçleri ve birbirleri ile olan ilişskilerini dikkate alarak hakimin karar verme süreçlerinde hataya düşmesini engelleyecek bir akl yürütme mekanizmasının geliştirilmesi mümkün müdür?

Buraya kadar hakimin karar verme sürecine odaklanarak belirli açıklamalarda bulunduk. Bu soruyu yanttlamadan önce ifade etmek gerekir ki burada önem arz eden husus yalnızca karar verme mekanizması olmayıp aynı zamanda hakimin modern ceza yargılamasındaki rolü ve etkileri de önemlidir.

Bir ceza yargılamasında hakimin davadan önce uyuşmazlık çözümünde bir rolü olduğu gibi yargılama sürecinin de yönetilmesinde büyük ve aktif bir rolü bulunmaktadır. Yine hakimler; kanunların uygulanması ve yorumlanmasında diğer hukuk dünyası üyelerinin yaklaşımlarına yön vermek konusunda eğitici bir role de sahiptirler. Toplum vicdanı denen kavramın yarg1daki bir nevi temsili olduklarından, kendilerini ifade etme şekilleri bile büyük bir önem arz etmektedir. Tüm bu etkenler bireyin-birey karşısındaki otorite duygusunu içselleştirmesini sağlamaktadır. Çocukken ebeveynlerimize olan içgüdüsel saygı ve itaat duygusu ilerleyen yaşlarda farklı etken ve sebeplerle farklı bireylere karş1 gelişmektedir. İşte bu noktada insan düşünmesi birebir robot hakim tarafindan taklit edilebilse bile insan hakimin sahip olduğu rol ve otoriteyi bünyesinde barındırabilir mi? sorusu gündeme gelmektedir. Bu soru bize göstermektedir ki söz konusu robot hakim kullanımı oldu mu buradaki tek sorun insan düşünmesinin birebir mekanikleştirilebilmesi değildir ${ }^{51}$. Nitekim ulusal hukukumuz bakımından bir ceza yargılamasında hakimin duruşmanın icrası, duruşmanın düzen ve disiplinini sağlaması, delil elde etme ve değerlendirme araçlarının hukuka uygunluğunun tespiti, delillerin ileri sürülmesi, tartışılması ve değerlendirilmesi ve sonuç olarak gerekçeli hükmün açıklanması gibi konularda sahip olduğu yetkiler ve sorumluluklar bütüncül bir şekilde değerlendirildiğinde hakimin düşüncesinin mekanikleştirilmesi, akışın eksiksiz bir şekilde yerine getirilmesi bakımından yetersizdir.

50 Perrone, s. 9-11.

51 Sourdin/Cornes, s. 97-98. 


\section{YAPAY ZEKANIN HUKUK DÜNYASINDAKİ YERİ}

Robot hakimlerin $^{52}$ karar verme mekanizmalarını açıklamak ve anlamlandırmak faaliyetlerine geçmeden önce günümüzde mevcut yarg1 sistemlerinde kullanılan tahmin teknolojilerine değinmek gerekir. Çünkü "robot hakim" denilen kavram aslında bu tahmin teknolojilerinin insan hakimin karar verme mekanizmasının taklit edilebilir seviyede gelişmiş halidir. Yapay zeka tahmin teknolojilerinin ceza yargılamasında kullanımı aslında oldukça yaygındır. Temelde yapay zekanın yargıda kullanım alanını üç başlık altında ele almak mümkün olup bizim çalışma konumuz bu yaygın alanın tahmin teknolojileri bölümü ile ilişkilidir.

\section{A. Bilgi Organizasyonu/Yönetimine İlişkin Sistemler}

Yapay zeka tahmin teknolojileri yargılama sürecinde büyük veri yığınlarının organizasyonunda büyük kolaylık sağlamaktadır. Elde edilen bilgilerin, olay ve olguların sisteme işlenmesi yargılama faaliyetlerinin hızland1rrlması ve bürokratik yükün hafiflemesi bakımından büyük bir önem taş1maktadır. Çünkü bu temel bürokratik süreçler çoğu zaman otomatik süreçlere tabi olup öngörülebilir neticeleri içermektedir. Bu yüzden de sonuçlar ne kadar öngörülebilir ise verilerin işlenmesi kısmen hatta koşulları sağladığı takdirde otomatik yapılabilmektedir. Böylelikle akıllı bir dosyalama portalının oluşturulması tarafların mahkemeye uyuşmazlığı mümkün olan en iyi şekilde taşımasını sağlar ${ }^{53}$.

Örnek olarak; ABD'de soruşturma öncesi elektronik delil ve bilgi toplanması ve bunların kategorize edilmesine yardımc1 olan "eDiscovery"; Ülkemizde ise UYAP ${ }^{54}$, TURKLEX ${ }^{55}$, ARYA ${ }^{56}$, HUKUK WORK ${ }^{57}$ yine

52 Doktrinde; robot hakim kavramı yerine insan ile yapay zekanın işbirliği içerisinde çalıştığı sistemler bakımından bir üst kavram olarak Ko-Robot(Co-robotics) kavramı kullanılması gerektiği ifade edilmektedir. Bu görüşü savunanlar temelde ikiye ayrılmaktadır. Bir görüş insan hakim ile robot hakim arasında bir iletişim olması gerektiği ve ortaya çıkan sorunlara ilişkin ortak hareket edilmesi gerektiği savunulmaktadır. Bir diğer görüşe göre ise insan hakim ile robot hakimin çalışmalarında birbirinden ayrı tutulması gerektiği ifade edilmektedir. Buocz, Thomas Julius: "Artificial Intelligence in Court Legitimacy Problems of AI Assistance in the Judiciary", Retskraft - Copenhagen Journal of Legal Studies, Volume 2, Number 1, Spring 2018, p. 42, 46, https://static1.squarespace.com/static/59db92336f4ca35190c650a5/t/5ad9da5f70a6adf9d 3ee842c/1524226655876/Artificial+Intelligence+in+Court.pdf, (E.T:12.04.2021).

53 Reiling, s. 3.

54 "Ulusal Yargı Ă̆ı Bilişim Sistemi kısa adıyla UYAP, günümüzün gerekli tüm teknolojik gelişmelerini kullanarak, Adalet Bakanlığ merkez ve taşra teşkilatının, bağlı ve ilgili kuruluşlarının, adli ve idari tüm yargı ve yargı destek birimlerinin donanım ve yazılım 
verilerin otomatik işlenmesi ile hızlıca belge oluşturarak zamandan tasarruf sağlayan Perfect NDA ${ }^{58}$ gibi uygulamalar bu kullanım alanına örnek gösterilebilir ${ }^{59}$.

\section{B. Tavsiye Veren/Destekleyen Sistemler}

Burada en yaygın örnekler dilekçe örnekleri, hakimlerin karar verme eğilimleri, ilgili konulara ilişkin mahkeme kararları gibi birçok alanda geliştirilmiş yapay zeka uygulamaları bulunmaktadır. Özellikle avukatlık mesleği bakımından mesleğin icrasını kolaylaştırmak ve özen yükümlülüğünün ifa edilmesine yönelik uygulamalar burada örnek gösterilebilir. Bu uygulamalara örnek verecek olursak ${ }^{60}$ :

- Yabancı literatürde "Due Diligence" olarak kullanılan kavram kabaca durum tespiti olarak ifade edilebilir. Mesleki uygulamalarda durum tespiti yapılması makul bir kişinin normalde başka bir tarafla bir anlaşma veya sözleşme veya belirli bir bakım standardına sahip bir eylemde bulunmadan önce yapması beklenen araştırma veya bakım uygulamasıdır ${ }^{61} . \mathrm{Bu}$

olarak iç otomasyonunu ve benzer şekilde bilgi otomasyonu sistemlerini kurmuş kamu kurum ve kuruluşlart ile dış birim entegrasyonunu sağlayan ve e-Dönüşüm sürecinde eAdalet ayağını oluşturan bir bilişim sistemidir.", https://www.uyap.gov.tr/Genel-Bilgi, (E.T:07.05.2021)

55 "TurkLex ${ }^{\circledR}$, hukukçuların tüm ihtiyaçlarını karşılamayı amaçlayan yapay zekâ ürünü yeni nesil bir yazılımdır. En güncel mevzuatlara ulaşabilmeyi, şahsi hukuki kütüphanelerin oluşturabilmesini, dava dosyalarının otomatik olarak oluşturabilmesini, davanızın sonuçlanma olasılığını analizlerle ön görebilmesini sağlayan bir sistemdir., https://www.turklex.com/hakkimizda/, (E.T:07.05.2021).

56 ARYA kendini "Şirketin her biriminde çalışabilen, SGK primi, stopaj, tazminat, yol ve yemek gibi masrafları olmayan bir "Dijital Çalışan" olarak tanımlamaktadır., https://www.arya-ai.com/, (E.T:07.05.2021).

57 "Hukuk Work Yapay Zekası (Artificial Narrow Intelligence); Bulduğunuz emsal kararların, direnme, düzeltme, HGK kararları ile ilişkilendirerek emsal olma gücünü, benzer içtihatların farklı yönlerini, ilgili olduğu kanun maddelerini, yerleşik görüşleri, görüş değişikliklerini, en güncellerinin bulunmasını sağlayan yardımcı bir yapay zeka yazılımidır.", https://www.hukukwork.com/, (E.T:07.05.2021).

58 https://www.neotalogic.com/product/perfectnda/, (E.T:07.05.2021).

59 Bacaksız/Sümer, s. 259; İçer, Zafer/Buluz, Başak: "Yapay Zekânın Ceza Muhakemesindeki Rolü ve Geleceği”, 9. Uluslararası Suç ve Ceza Film Festivali, İstanbul Üniversitesi, 2019, s. 6-13, https://www.academia.edu/41074795/YAPAY_ZEK\%C3\% 82NIN_CEZA_MUHAKEMES\%C4\%B0NDEK\%C4\%B0_ROL\%C3\%9C_VE_GELE CE\% $4 \%$ \% $\%$ C4\%B0, (E.T:07.05.2021).

60 Bacaksız/Sümer, s. 259-260.

61 İçer/Buluz, s. 7-8. 
uygulamanın yapılmasını sağlayan yapay zeka yazılımlarına örnek verecek olursak:

- Avukatlar için yardımcı yazılımların ülkemizdeki örnekleri Kazancı, Lexpera, Sinerji gibi içtihat bilgi bankalarıdır. Bu hukuk otomasyonları aynı zamanda dilekçe hazırlanması, dilekçe örneklerine ulaşılması, güncel hukuk hakkında bilgi sahibi olunması, mevzuata ulaşılması, duruşma takip edilmesi gibi birçok başka kolaylık da sağlamaktadır.

- "eBRAVIA" adlı yapay zeka uygulaması yüksek hız ve doğrulukla sözleşme analizi ve durum tespiti yapabilmektedir. Manuel inceleme süresini \% 30-90 oranında azaltırken aynı zamanda sonuçların doğruluğunu da arttırmaktadır. 50'den fazla belgeyi bir dakikadan daha kısa sürede analiz etmekte ve önemli bilgilerin kaybolması riskini en aza indirmektedir ${ }^{62}$.

- "LawGeex" adlı yapay zeka uygulaması ise: sözleşme incelemeleri yaparak hedeflenen stratejiye göre sözleşmeyi gerektiğinde yeniden yap1landırabilmektedir. Bu şekilde zamandan tasarruf ederek aynı zaman da maliyeti düşürmektedir ${ }^{63}$.

- "TradeMark Now" isimli yapay zeka kurumsal şirketler, hukuk firmaları ve marka ajansları tarafindan kullanılan; anında ticari marka araması yapılması ve elde edilen sonuçların izlenmesi için web tabanlı ticari marka yönetim platformu sunmaktadır ${ }^{64}$.

- "Anaqua Studio" isimli şirket tarafindan geliştirilen "AcclaimIP" adlı yapay zeka yazılımı; patent araştırmaları yapmak, patentleri analiz etmek ve patentlenebilirliği belirlemek için en hızlı, en sezgisel ve kapsamlı çözüm yolunu sunmaktadır ${ }^{65}$.

\section{Tahmin Sistemleri}

Bizim çalışmamız için önem arz eden yapay zeka uygulamaları tahmin teknolojileridir. Uygulamada mahkemelerin davaları öngörülemeyen bir şekilde neticelendirme riski bulunmaktadır. Somut olayda ne kadar bilgi ve soru var ise bu risk de o derece artmaktadır. İşte bu noktada yapay zeka tahmin uygulamaları bu riski mümkün mertebe azaltmaya yönelik bir amaç doğrultusunda geliştirilmektedir. Bu sistemlere örnek verecek olursak:

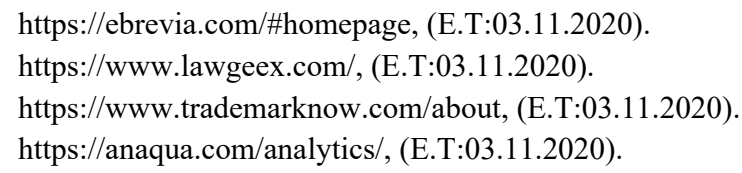


\& Şu anda ABD ceza yargılamasında özellikle de bireylerin mahkum olma olasılıkları ve aktüeryal verilerine dayanılarak tekrar suç işleme olasılıklarına yani tekerrür olasılıklarını hesaplarken yapay zeka tahmin teknolojilerinden yararlanmaktadır. Bu yararlanma beraberinde hukuki tartışmaları ve dezavantajlı hususları da getirmektedir. State v. Loomis, the Supreme Court of Wisconsin davasında; yapay zeka tahmin algoritması kullanılarak mahkemede yapılan tekerrür risk değerlendirmesinin adil yargılanma hakkını ihlal edilmediğine kanaat getirmiştir. Burada ilgi çekici olan nokta, ne mahkeme ne de sanıklar algoritma yapısından yargılama sürecinde gerçekten haberdar değildi ${ }^{66}$.

* Yine Amerika Birleşik Devletleri'nde bir grup akademisyen tarafindan geliştirilen "SCOTUS" isimli makine öğrenmesi uygulamasının Birleşik Yüksek Mahkemede görülen bir davanın sonucunu \% 70,2 ve hakimlerin oy kullanma davranışlarını \% 71,9 doğrulukla tahmin edebileceğini iddia edilmiştir. $\mathrm{Bu}$ uygulama vakayla ilgili bilgilere ek olarak, hakimlerin siyasi tercihleri ve geçmişteki oy verme davranışlarından da yararlanmıştı́ ${ }^{67}$.

* Benzer bir amaç için geliştirilen " $E C t H R$ " isimli doğal dil işleme ve makine öğrenmesi yöntemlerini kullanan yapay zeka tahmin uygulamasi konuları ve metinlerdeki benzer yapılardan yolan çıkarak, HUDOC veri tabanında yer alan kararları analiz ederek Avrupa İnsan Mahkemesi Kararlarını $\% 79$ oranında tahmin edebilmiştir ${ }^{68}$.

* Amerika'da geliştirilen bir diğer tahmin teknolojisi "COMPAS" isimli yapay zeka programıdır. Bu program suçlunun tekerrür riski verilerine bakarak erken tahliye ya da tutukluluk halinin devamına gibi kararlarda duruşma öncesi mahkemeyi bilgilendirmek için kullanılmaktadır. Program tekerrür riskini hesaplarken şüpheli/sanık sabıka kaydı, 137 sorudan oluşan bir anket neticesinde elde ettiği veriler gibi hususlardan yararlanmaktadır. Bu programla ilgili güvenilirlik sorunu yaratan husus Afro-Amerikan vatandaşların tekerrür riskini mevcut koşullar karşısında abartılı hesaplamasıdır. $\mathrm{Bu}$ yaklaşımı 1rkçı görülerek eleştiriye açık bir durum yaratmaktadır ${ }^{69}$.

\footnotetext{
66 Perrone, s. 5.

67 Reiling, s. 5.

68 Bu yapay zeka uygulamasının dezavantajı yönlerine ilişkin detaylı bilgi ve bu konuda yapılmış deney verileri için bakınız: Medvedeva, Masha/Vols, Michel/Wieling, Martijn: "Using machine learning to predict decisions of the European Court of Human Rights", Artifcial Intelligence and Law”, 28, 2020, s. 237-266 https://doi.org/10.1007/ s10506-019-09255-y, (E.T:05.04.2021).

69 Reiling, s. 5-6.
} 
Bir başka örnek Almanya'da "Argumentum" adında geliştirilen yapay zeka projesidir. Argümantasyon bilimsel disiplinler için önem arz eden bir husustur. Bu nedenle güçlü ve ikna edici argümanların geliştirilmesi ve mevcut argümantasyon yapılarının analizi başta beşeri bilimler alanında ve özellikle hukuk alanında önem arz etmektedir. Adli yargılama sürecinde yapılan argümantasyon faaliyetleri entelektüel bir çaba ve arka planında potansiyel olarak çok fazla bilgi gerektirir. Yargı sürecinde görev alan bireylerin doğası gereği bu görevlerini yerine getirirken bilgi işleme kapasitelerinin bir sınırı bulunmaktadır. İște bu noktada bu derece yoğun bilgi ve zaman gerektiren bir görevin yapay zeka teknolojisi ile nasıl desteklenebileceği bu projenin çıkış noktası olmuştur. Bu proje argüman yapılarının otomatik olarak tanımlanmasını, analiz edilmesini ve önerilmesini destekleyen bir yazılım prototipi niteliği taşımaktadır. Bu yapay zeka projesinin örneksel temelini de Alman Federal Anayasa Mahkemesi kararları oluşturmaktadır $^{70}$.

\& Rusya' da ise devlet tarafından işletilen en büyük kredi kuruluşu olan Sberbank, bir şirketin yasal kapasitesini manuel müdahale olmadan kontrol etmesini sağlayan bir yapay zeka sistemi oluşturdu. "Robot Avukat" olarak bilinen bu sistem açıklanmasından önceki sekiz ayda robot avukat 2,5 milyondan fazla yasal görüş yayınlamıştır. Sberbank, robot avukatın iş süreçlerini önemli ölçüde hızlandırdığını ve büyük miktarda veriyi manuel olarak işlerken ve yüklenicileri doğrularken kaçınılmaz olan hataları önlediğini söylemişti ${ }^{71}$.

Meksika'da Buenos Aires'te savcılık tarafindan geliştirilen yapay zeka uygulaması "PROMET", mahkemeye ulaşan konut itirazları kararlarına odaklanmıştır. Bu alandan yola çıkan uygulama ödenmemiş para cezalarının infaz edilmesi, sabıka kaydı nedeniyle taksi ruhsatının reddi ve cinsiyete dayalı şiddet şikayetleri gibi durumlarda; temyiz metnini ve önceki eylemleri analiz ederek ve sistemde önceden yapılandırılmış belirli anahtar kelimelerin

70 Houy, Constantin/Niesen, Tim/Fettke, Peter/Loos, Peter: "Towards Automated Identification and Analysis of Argumentation Structures in the Decision Corpus of the German Federal Constitutional Court", Institute for Information Systems (IWi) at the German Research Center for Artificial Intelligence (DFKI) and Saarland University Saarbrücken, Germany, https://www.dfki.de/fileadmin/user_upload/import/6833_ IEEE_DEST_2013_Houy_Niesen_Fettke_Loos-ARGUMENTUM.pdf, (E.T:05.04.2021).

71 https://www.computerweekly.com/news/252491484/Robot-lawyer-gets-Sberbankrole\#: :text=Russia's $\% 2$ largest $\% 20$ state $\% 2$ Drun $\% 20$ lender,legal $\% 20$ capacity $\% 20$ with out $\% 20$ manual $\% 20$ intervention.\&text $=$ The $\% 20$ robot $\% 20$ lawyer $\% 20$ processes $\% 20$ docu ments,of\%20Sberbank's\%20executive\%20board., (E.T:05.04.2021). 
varlığını doğrulayarak isteğe uygun yanıtları tahmin yoluyla sunmaktadır. Promet programlayıcılarına göre; ortaya koyduğu tahminler \%96 doğruluğa sahip olacaktır ${ }^{72}$.

\& Yine Meksika'da katip ve hakimlere danışmanlık hizmeti sunan "The Expertius" adlı yapay zeka sistemi örnek gösterilebilir ${ }^{73}$.

* Hollanda' da mahkemelere dolandırıcılık suçlarıyla mücadele için yardımcı bir yapay zeka tahmin teknolojisi geliştirilmiştir. Otomatik, makine öğrenimi (ML) aracı olan "Sistem Risk Göstergesi (SyRI)", yerel Hollandalı yetkililer tarafından, yüksek dolandırıc1lık riski altında olduğundan şüphelenilen kişilerin profillerini ve listelerini hazırlamak için kullanılmıştır. SyRI geçmişte sosyal güvenlik dolandırıcılığı yapan kişilerden risk profilleri oluşturarak "benzer" vatandaş profillerini taramaktadır. Bu tarama neticesinde dolandırıcılık yapabilecek veya yüksek risk taşıyan kişilere yönelik potansiyel soruşturmalar için tahminler sunmaktadır. Bu algoritmanın kullanıldığ dönemlerde; çoğunlukla düşük gelirli ve azınlık sakinlerinin bulunduğu mahalleleri hedef alındığ 1 için masum insanları suç şüphesi altında bırakması gerekçesiyle ağır bir şekilde eleştirilmişti ${ }^{74}$.

* İngiltere'de "Traffic Penalty Tribunal" adlı online trafik ceza mahkemesi; sürücülerin İngiltere'deki (Londra dışında) ve Galler'deki yerel makamlar ve ücretlendirme makamları tarafindan park ve trafik ihlalleri nedeniyle verilen Ceza Ücreti Bildirimlerine (PCN'ler) karşı itirazlar hakkında karar veren bir nevi temyiz merciidir. Başvurular 300'den fazla yerel makam tarafindan İngiltere ve Galler'de park etme, otobüs șeridi, araçların çöpü ve (yalnızca Galler'de) hareketli trafik ihlalleri için verilen cezalara karşı itirazları içermektedir. Bu online Trafik Ceza Mahkemesine itiraz etmek tamamen ücretsizdir. Sürücü temyiz başvurusunu kaybetmesi halinde ödemesi gereken tek şey, Ceza Ücreti Bildirimi’nin (PCN) tamamıdır.

Sürücü online yapacağı başvuruda; belgeler, fotoğraflar, telefonunda yer alan mesajlar başta olmak üzere itirazını gerekçelendirmeye yardımcı olacak her türlü bilgiyi kullanabilmektedir. Yine sürücünün yaptığı bu başvuru nedeniyle mahkemeye gitmesine gerek yoktur. Hizl, kolay ve tamamen çevrimiçi olarak yürütülen bu süreç her somut olayda farklılık göstermekle

72 https://www.world-today-news.com/artificial-intelligence-and-the-judicial-system-inlatin-america/, (E.T:05.04.2021).

73 Sourdin, Tania/Cornes, Richard: "Do Judges Need to Be Human? The Implications of Technology for Responsive Judging”, Chapter in The Responsive Judge (pp.87-119), s. 89, https://www.researchgate.net/publication/326244385, (E.T:05.04.2021).

74 "https://www.zdnet.com/article/dutch-court-rules-ai-benefits-fraud-detection-systemviolates-eu-human-rights/, (E.T:05.04.2021). 
birlikte çoğu dava 14 gün içerisinde neticelendirilmektedir. Yine görülen davaların \%97'si tamamen çevrimiçi olarak gönderilip ve karara bağlanırken; davaların \%50'den fazlası 14 gün içinde ve $\% 75$ 'i 28 gün içinde sonuçlandırılmaktadır. İtiraz süreci boyunca yargılamayı başından sonuna kadar takip edilebilmekte; masaüstü bilgisayarlarda, dizüstü bilgisayarlarda, tabletlerde ve akillı telefonlarda kullanılabilmektedir. Karar verme ve yargılama sürecinde ise yarı zamanlı çalışan hakimler ve atamaları Büyük Britanya Lord Şansölyesinin onayına tabi olan bağımsız avukatlardan oluşmaktadır ${ }^{75}$.

"Ravel" isimli şirket tarafindan geliştirilen yapay zeka yazılımları; hakimlerin nasıl düşündüğü, yazdığı ve yönettiği konusunda kullanıcılarına içgörü kazandırmakta, her mahkemeyi benzersiz kılan dilin ve içtihatın tespitini sağlamaktadır ${ }^{76}$.

* "Lex Machine" adlı yapay zeka hukuk avukatlar tarafindan yeni müvekkiller bulmak ve almak ve davaları kazanmak için kullanılmaktadır. $\mathrm{Bu}$ yapay zeka yazılımı "Lexpressions" adlı arama motoru sayesinde milyonlarca sayfalık dava bilgilerinden elde edilerek derlenen hakimler, avukatlar, taraflar ve davaların konuları hakkında yaptığ 1 araştırmalar neticesinde daha önce hiç mevcut olmayan bir iç görü ortaya koymaktadır ${ }^{77}$

* "PreMONITION" isimli şirket hukuk alanında şirketlerin avukatları işe alımlarında performans analizleri elde eden, risk altındaki devam etmekte olan davalara ilişkin çözüm üretilebilmesi için analizler yapan, dava türüne göre dava süresi, hakimlerin tutumu, karşı tarafin vekiline ilişkin stratejik bilgileri analiz ederek sonucun öngörülmesini sağlayan yapay zeka tahmin teknolojileri üretmektedir ${ }^{78}$.

\section{ROBOT HAKIMIN KARAR VERME MEKANIZMASI}

Buraya kadar verilen örneklerden görüldüğü üzere yapay zekanın hukuk dünyasındaki kullanım alanı çok geniş olup her geçen gün daha da genişlemektedir. Bu örneklerden yola çıkarak ifade etmek gerekir ki "robot hakim" uygulaması ütopik bir örnek/olasılık olmayıp günümüzde fiilen robot hakimlerin görev yaptığı/yapması planlanan uygulamalar bulunmaktadır:

- 2017 yılında Çin'in Hangzhou şehrinde kurulan ve Aralık 2019 yılında kullanıcıların Mart-Ekim ayları arasında mahkeme sistemini kulla-

75 https://www.trafficpenaltytribunal.gov.uk/faq/, (E.T:07.04.2021).

$76 \mathrm{https} / /$ home.ravellaw.com/products-and-technology, (E.T:03.11.2020); Bacaksız/ Sümer, s. 261.

77 https://lexmachina.com/about/, (E.T:03.11.2020); Bacaksız/Sümer, s. 261.

78 https://premonition.ai/legal_analytics/, (E.T:03.11.2020); Bacaksı/Sümer, s. 261. 
narak 3,1 milyondan fazla yasal faaliyeti tamamladığ 1 bildirilen "Internet Mahkemeleri" robot hakim uygulamasının bir başka örneği niteliğindedir. "AI Judge (Yapay Zeka Yargıç)" isimli yapay zeka sistemini kullanan bu mahkeme daha sonra Pekin'de de kurulmuştur. Bu İnternet Mahkemelerinde robot hakimler görev almakta olup tarafların davalarını çevrimiçi olarak kaydetmelerine ve sorunlarını dijital duruşma yoluyla çözmelerine olanak tanınmaktadır. Bu mahkemede yalnızca dijital konulardaki hukuki uyuşmazlıkları içeren davalar görülmektedir. Örneğin; fikri mülkiyet, e-ticaret, elektronik ortamda gerçekleştirilen davranışlarla ilgili mali anlaşmazlıklar, çevrimiçi olarak alınan veya gerçekleştirilen ürünler, interneti içeren mülkiyet ve medeni haklar davaları gibi çeşitli hukuki uyuşmazlıklar ele alınmaktadır. İnternet mahkemelerindeki davacıların neredeyse yüzde 80 'i bireyler ve yüzde 20'si tüzel kişiler olup kararların yüzde 98'i temyizsiz olarak kabul edilmiştir. Mahkemenin kuruluşundan bu yana yaklaşık 73.000 avukatın yanı sıra bir milyondan fazla vatandaşın sisteme kaydolduğu duyurulmuştur. İnternet mahkemelerinde hakim ile iletişim kurabilmek için video mesajlaşma sistemi veyahut dilekçe kullanılmaktadır. Robot hakim; kadın suretinde tasarlanan bir ara yüz aracıllğıyla vatandaşlarla iletişime geçmektedir. Holografik bir şekilde yansitılarak farklı insan hakimlerden esinlenerek 3 boyutlu bir görüntü oluşturulmuştur. Bu mahkemede görev alan hakimler haftanın yedi günü yirmi dört saat görev yapmaktadırlar ${ }^{79}$.

- Benzer bir örneği Estonya bakımından da vermek mümkündür. Estonya'da hayata geçeceği tarih belli olmayıp henüz başlangıç aşamasında olan bir yapay zeka hakim projesi bulunmaktadır. Bu proje kapsaminda üretilecek yapay zeka hakimler; yasal birçok dokümanı analiz ederek kendisine verilen algoritmalar doğrultusunda karar verecektir. Bu yapay zeka hakimler başlangıç olarak 7.000 Euro' dan daha az tutarlı hukuki uyuşmazlıklara bakacak olup bu hakimlerin verdikleri kararlar bağlayıcı olacak ve bu kararlara ilişkin itiraz yolu açık olacaktır ${ }^{80}$.

Robot hakimlerin karar verme süreçlerini anlayabilmek adına yukarıda verilen örneklerin işleyişiyle ilgili birtakım açıklamalar yapmak gerekir.

Yukarıda verilen bu örneklerin büyük bir çoğunluğunda karar verme süreçlerinde etkili olan temelde iki parametre bulunmaktadır. Bunlardan ilki

79 https://www.lexisnexis.ca/en-ca/ihc/2020-02/robot-justice-chinas-use-of-internetcourts.page, (E.T:13.06.2021); https://learningenglish.voanews.com/a/robot-justice-therise-of-china-s-internet-courts-/5201677.html, (E.T:13.06.2021)

80 https://www.dijifi.org/2019/03/robot-hakim.html, (E.T:13.06.2021); Bacaksız/Sümer, s. 264-265. 
gerekli verilerin toplanmast ve analiz edilmesi ikincisi ise verilerin kullanımı ile ilgili kısitlayıcı kuralların tespit edilebilmesidir. Burada bu parametlerelerin kullanımı aslında biraz da algoritmanın karar verme sürecinde hangi sistemi (Kural tabanlı, Bilgi tabanlı, Dava tabanlı, Çerçevelerin ve Semantik bağların incelenmesi gibi) kullandığı ile de ilgilidir.

Yukarıda verilen örneklerde genellikle dava tabanlı sistem karar verme süreçlerinde kullanılmaktadır. Bu sistem ağırlıklı olarak hukuk otomasyonları için geliştirilmektedir. Bu nedenle dava tabanlı sistem hakkında genel bir bilgi vermek işleyişi anlamak adına yardımcı olacaktır. Dava tabanlı muhakeme CBR (Case Based Reasoning), deneyimlerden veya "eski durumlardan”, problemleri çözme çabalarından yola çıkarak önerilen çözümler konusunda eleştirilerde bulunmak ve anormal durumları açıklamak için akıl yürütme anlamına gelmektedir. CBR, davaları kaydetmek ve dizinlemek için kullanılabilecek bir dizi kavram ve teknik anlamına gelmekte ve ardından sunulduğunda yeni vakaları çözmede faydalı olabilecek verileri tanımlamak için kullanılmaktadır. Burada ifade etmek gerekir ki Hollanda' da yapılan bir e-mahkemenin karar sürecine ilişkin bir vaka çalışmasında yalnızca bir sistemin kullanılmadığı çok daha karmaşık olduğu sonucuna varılmıştır ${ }^{81}$.

$\mathrm{Bu}$ araştırma tespitinden ve kısa açıklamalardan hareketle birden fazla farklı sistemden yararlanılarak uygulamada uyuşmazlıkların çözümü için birçok teknoloji geliştirilmiştir. Bu teknolojilerin işleyişi de robot hakimin çalışma mekanizması hakkında bizlere bir öngörü sağlayacağı için kısaca ele almak gerekir. Çünkü örnek üzerinden yapılacak açıklamalar ileride robot hakimin muhakeme sürecine ilişkin değineceğimiz hususları somutlaştırmak için büyük önem arz etmektedir.

Burada öncelikle Alternatif Uyuşmazlık Çözümü (ADR-Alternative Dispute Resolution) ve Online Uyuşmazlık Çözümü (ODR- Online Dispute Resolution) hakkında kısaca bilgi vermek gerekir. Bazen 'mahkeme dışı uyuşmazlık çözümü' olarak da adlandırılan Alternatif uyuşmazlık çözümü (ADR); tüketiciler arasındaki anlaşmazlıkları çözmek için bir prosedür gerektirmeksizin uyuşmazlığı yargıya taşımadan kullanılan bir çözüm yöntemidir. Burada tarafsız bir ADR organı vasıtasıyla süreç yönetilmektedir. ODR ise; E-ticaretin büyümesinin yanı sıra, çevrimiçi satın alımlarla ilgili anlaşmazlıkların da büyümesi neticesinde tüketicilerle/müşterilerle olan

81 Nakad, Henriette/Herik, H. Jaap Van Den/Jongbloed, Anthonie/M. Salem, AbdelBadeeh: "The Rise of the Robotic Judge in Modern Court Proceedings", ICIT 2015 The 7th International Conference on Information Technology, s. 63-64, https://www.researchgate.net/publication/300720949, (E.T:08.04.2021). 
uyuşmazlıklarda yardımcı olmak için Avrupa Komisyonu tarafından sağlanan çevrimiçi uyuşmazlık çözüm yöntemidir. ODR sisteminin çalışma sürecinde temelde üç aşama bulunmaktadır.

Öncelikle anlaşmazlık çözümüne ilişkin çeşitli unsurlar sisteme dahil edilmektedir. Burada temelde anlaşmazlıkların doğmasını önlemek ve eğer bir uyuşmazlık doğmuş ise çözüm üretmek gibi iki amaç bulunmaktadır. Burada ilk aşamada yapay zeka algoritması anlaşmazlığı tanımlamaktadır. $\mathrm{Bu}$ süreçte taraflar(kullanıcılar) çevrimiçi bir şekilde tanımlanan uyuşmazlığı düzenleyip derleyebilmektedirler. Sonraki aşamada sadece yazılımın rol oynadığı bir aşama söz konusu olmaktadır. Burada yapay zeka birden fazla faktör ile ilgili çeşitli kurallar uygulayarak çözüm üretme sürecine geçmektedir.

Örnek verecek olursak; Amazon'da s1k s1k online alışveriş yapan üyeler veya Amazon Prime üyelerinin, eğer seyrek olarak iade edilen bir ürün ise veya değeri düşük ya da çok fazla şikayete konu olmuş bir ürün ise ürünün iadesi, geri ödemesi, değiştirilmesi gibi bir talep söz konusu olduğunda yapay zeka insan müdahalesi olmaksızın işlemi gerçekleştirebilmektedir. Yine bu şekilde tüketici deneyimleri geliştirilerek insan gücü kullanımı azaltılmakta, daha ekonomik bir iş modeli sağlanmaktadır. Bu iş modelinde görülmektedir ki insan kaynakları biriminde görev alan insan personelin görevini yapay zeka birebir kopyalamaktadır.

Son olarak yapay zekanın çözüm üretilebilmesi için toplu miktarda veri toplayarak yeniden analiz edip kullanması söz konusudur. Burada algoritma aslında karar verme sürecinde etkili olacak desenleri oluşturmaktadır. Bu temel üç aşamaya bakıldığında karar verme sürecinde genel olarak şu şekilde adımların izlendiği görülmektedir:

Sorunun tespiti

回 Somut olaydaki değişkenlerin tespit edilerek ispat usulüne göre gerekçelendirilmesi

㽞 İlgili yasal çerçevenin belirlenmesi

Tarafların ilgilerinin tespit edilmesi

皿 Taraflarının duygularını ifade edebilme imkanı yaratılması

邑 Sorunların ayrıştırılması

皿 Uyuşmazlık taraflarının konumlarının belirlenmesi

巴⿴囗十⿱ Bilgi değişimi ve akışının sağlanması

皿 Çözüm için tahmin/öneri sunulması

昷 Uyuşmazlık çözümü için bir zaman dilimi belirlenmesi 

sunmaktır ${ }^{82}$.

Son adımda taraflara bir anlaşma sağlamak ya da bağlayıcı çözümler

Bu çözüm yöntemlerinde kullanılan yapay zeka algoritmalarının işleyişinden yola çıkarak bazı genel açıklamalar yapacak olursak:

Burada robot hakim bakımından karar vermeyi sağlayacak algoritmanın mümkün olan en doğru sonucu elde edebilmesi için bir dizi soru sorulması, bu sorulara verilen yanıtlar çerçevesinde elde edilen veri yığınlarını anlamlandırması ve sınıflandırması, doğru bilgiler elde etmek için uyuşmazlığa yönelik sorular sorması ve tüm elde ettiği veriler çerçevesinde kendi karar ağaçlarını oluşturması gerekmektedir. Burada önem arz eden husus veri setlerinin sürekli gözden geçirilmesi gerektiği ve yeni gelen veri setlerinin değerlendirmeye tabi tutulması zorunluluğudur. İşte bu döngü insan hakim bakımından bilinçsiz veyahut önyargılı tercihlerin doğmasına sebep olmaktadır. Robot hakim ile bu sürecin mekanikleştirilmesi ile bu sorunun mümkün mertebe önüne geçilmek hedeflenmektedir.

$\mathrm{Bu}$ açıklamayı somutlaştırmak adına Hollanda'da, "Rechtwijzer" adlı gelişmiş bir ODR programından söz etmek gerekir. Program çiftlere boşanma işleminde yardımcı olmak için birtakım araçlar sunmaktadır. Rechtwijzer, taraflar ve ilişkileri hakkında sorular sorarak elde ettiği veri kümeleri sayesinde uyuşmazlığa ilişkin cevaplar üretmiştir. Sorulan sorulara verilen giriş bilgilerine göre bilgi, araçlar, diğer web sitelerine bağlantılar ve kişisel tavsiyeler üretmiştir. Bu şekilde tarafları kendileri arasındaki anlaşmazlıklarını çözmeye teşvik etmiştir.

Fakat burada önemle ifade etmek gerekir ki robot hakimin sahip olacağı tahmin algoritması ile paylaşılan verilerin taraflı ya da müdahaleye aç1k olması veyahut algoritmanın kendisine programlayıcının bireysel eğilimleri veya önyargıları da gömülü (coded bias) olabilir. İşte bu noktada robot hakim insan hakime benzer bir şekilde vereceği kararlarda ayrımcılık yasağına aykırı hareket edebilir, önyargılı veya taraflı kararları çıktı olarak sunabilir. Çünkü burada robot hakim kendisine sunulan kanıtları algoritmasında gömülü olan önyargı nedeniyle uyuşmazlığı önyargılı bir şekilde tanımlayarak analiz edecektir ${ }^{83}$. Yine bu yazılımların bizlere "akıllı" görünmesinin ardındaki etken çıktıların tahmin edilemez oluşu veya deneyimlerle öğrene-

82 Morison, J./Harkens, A.: "Re-Engineering Justice? Robot Judges, Computerised Courts and (Semi) Automated Legal Decision-Making”, Legal Studies, 39(4), 2019, s. 3-4, https://doi.org/10.1017/lst.2019.5, (E.T:06.04.2021).

83 Sourdin/Cornes, s. 92-96; Buocz, s. 44. 
bilme yetilerinin olmasıdır. Fakat unutmamak gerekir ki yapay zeka yalnızca sahip olduğu programlama kadar iyidir. Robot hakim için kullanılacak bir yapay zeka sistemi kendi başına adli akıl yürütmeyi açıklayamaz yalnızca kendi öğrenme yöntemi ve elde ettiği veriler neticesinde (kendisine yüklenen kararlar arşivindeki korelasyon ve mantık adımlarını önceden analiz ederek) bir karar çıktısı sunabilir. Bu nedenle yapay zekanın bir kapalı kutu olması ve karar sürecinin gözlemlenebilir ve açıklanabilir olmayışı beraberinde şeffaflık sorununu getirmektedir ${ }^{84}$.

Robot hakimin karar sürecinde dair bir diğer değinilmesi gereken husus makine öğrenmesinde yapay zekanın kendisine verilen mevcut verilerle ne kadar ilerleyebileceğidir. Robot hakim kendisine verilen bilgiye benzer bir bilgi söz konusu ise faydalı ve isabetli bir şekilde bu bilgiyi analiz edebilecektir. Çünkü makine öğrenmesiyle desenleri keşfetme ve etkili bir genelleme yapabilmek için kendisine önceden verilen örnek davaların boyutu yeterli olmayabilecektir. Bir başka deyişle robot hakim somut olay ile kendisine verilen verilerde bir benzerlik ya da bağlantı yakalayamaz ise, somut olay özelinde isabetli bir çıktı sunamayacaktır. Çünkü bu makine öğrenmesinin verdiği yeteneğin çok daha ötesinde her zaman yeni bir öğrenme örüntüsünü gerektirmektedir. Burada aslında robot hakimden beklenen bir insan hakim gibi iç görüye sahip olmasıdır.

Yapay zeka algoritmalarına iç görü kazandırma alanında yapılan bazı başarılı çalışmalar bulunmaktadır. Fakat bu örnekler hukuk alanında değildir. Hukuk alanında bu denli bir iç görünün henüz sağlanamamış olasındaki temel etkenlerden biri hukuk dünyasına ait terimlerin ve yasal düzenlemelerin koda çevrilememesi yani yapay zekanın anlayacağı dile uyarlanmamış olmasındadır $^{85}$. Yapay zeka tahmin algoritmalarının sosyo-yasal düzene tamamen uyum sağlayabilmesi ve etkin bir şekilde kullanılabilmesi için makine öğrenmesinin bir insan hakim seviyesine gelmesi ya da büyük veri yığınlarını otonom olarak kullanabilmesi gerekmektedir ${ }^{86}$.

$\mathrm{Bu}$ gelişmişlik seviyesine ulaşabilmek ve robot hakimin karar verirken algoritmasında yasal bilgileri etkili bir şekilde işleyebilmesi için öncelikle yasal bilgilerin makine öğrenmesine uygun bir veri haline getirilerek işlenebilir hale getirilmesi gerekmektedir. Robot hakimlerin karar verme süreçlerinde dil çok önemli bir faktördür. Burada kararların doğruluğunu arttırmak istiyorsak yasaların ve gerekçeli kararlarda kullanılan dilin yapay zeka

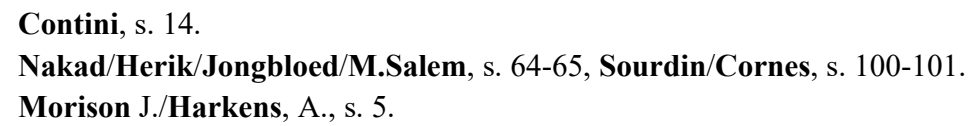


tarafından işlenebilir hale gelmesi büyük önem arz etmektedir. Peki bu nasıl sağlanabilecektir?

Öncelikle ifade etmek gerekir ki ağırlıklı olarak kağıt üzerinde yer alan bir hukuk sisteminin dijitalleştirilmesi, sayısallaştırılması zor ve komplike bir süreci beraberinde getirmektedir. Her ne kadar birçok hukuki konuda genel bir yasal çerçeve olsa da mahkemelerin ve genel olarak adliyenin işleyişi içerisinde insan faktörü olduğu için farklı uygulamaların ve kararların geliştirildiği bir uygulama söz konusudur ${ }^{87}$.

Bunun için öncelikle kelimelerin kanun içerisindeki anlamı, kelimenin yapıs1, benzer örneklemler içerisindeki kullanımı, metinsel okunabilirlik, belgenin yapısı, yapılandırılmış bir hukuk terminolojisi, temel hukuk ilişkilerinin tanımlanması ve yeterli veri kümesinin sağlanması gibi konularda çalışmaların yapılması gerekmektedir. Çünkü yapay zekanın karar ağacında evet ya da hayır gibi basit kararlardan ziyade çok daha komplike ve birçok değişkenin önem arz ettiği hukuk dünyasına has kararlar alması gerekmektedir $^{88}$.

Tüm bu faaliyetler yerine getirilirken disiplinlerarası bir iş birliği kaçınılmazdır. Yapay zeka programlayıcıları, hukukçular, dilbilimciler, devlet yönetiminde görev alanlar gibi teknik kavramlar ve bağlamlar anlamında yetkin kişilerin birlikte çalışması gerekmektedir. Tabi ki yasaların ve hukuk dünyasında ait kavramların koda çevrilmesi yeterli olmayıp aynı zamanda doğru kodlamanın yapılıp yapılmadığı, güncel değişikliklerin revize edilip edilmediği, yeni içtihatların mevcut olup olmadığı gibi hususların sistematik bir şekilde denetlenmesi gerekecektir. Bu ihtiyaçlar göstermektedir ki gelecekte farklı meslek gruplarının da yazılım ve programlama alanlarında yeter seviyede bir eğitim almasını da gerekecektir ${ }^{89}$.

\section{ULUSLARARASI BELGELER}

Buraya kadar değinilen hususlarda görüldüğü üzere robot hakim uygulamasının getireceği sorunların yoğunlaştı̆̆ temel alanlardan biri de "etik"tir. Çünkü yargısal faaliyetler ve yargı organlarının tabi olduğu etik kurallar değişken olup genel geçer tespitlerin yapılması güçtür. Bununla birlikte günümüzde hakimlerin tabi olduğu Bangalor Yarg1 Etiği İlkeleri, savcıların tabi olduğu Budapeşte ilkeleri veyahut avukatların tabi olduğu Uluslararası

\footnotetext{
Contini, s. 7.

Reiling, s. 8-9.

Contini, s. 6; Sourdin, s. 1127.
} 
Barolar Birliği kuralları gibi örnekler de mevcuttur ${ }^{90}$. Söz konusu yapay zekaya sahip bir robot hakim olduğunda bu şekilde örnekler yaratmak daha da güçleşmektedir. Çünkü ortaya konulan bu evrensel etik ilkeler için gerçek kişiler esas alınmıştır. Hal böyle iken bizlere bu konuda yol gösterecek olan bu konuya ilişkin uluslararası belgelerdir. Elbette robotlar ya da yapay zekaya ilişkin çok sayıda uluslararası düzenleme ya da belge mevcuttur. Bizler bu çalışmada doğrudan robot hakimleri konu alan veyahut doğrudan ilgili olan iki önemli belgeye değinmeyi konudan çok uzaklaşmamak adına yeterli gördük.

\section{A. Avrupa Konseyi’nin Etik İlkeleri}

Değineceğimiz belgelerden ilki Avrupa Konseyi Avrupa Adaletin Etkinliği Komisyonu (CEPEJ) tarafından 2018 yılında yayınlanan "Yargılama Sisteminde Yapay Zeka Kullanımına Dair Etik Şart” ${ }^{91}{ }^{91}$. Söz konusu etik şartta yarg1 sisteminde yapay zeka kullanılırken uyulması gereken beş temel ilkeden söz edilmektedir:
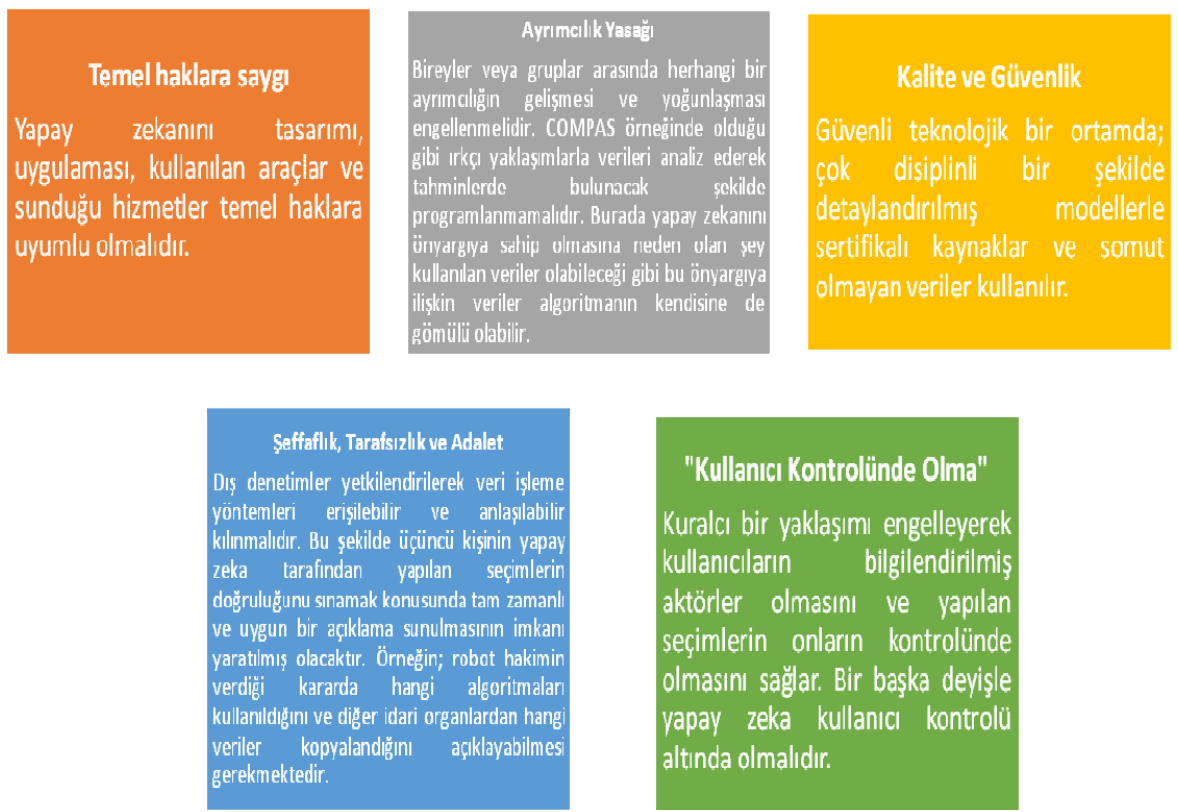

$90 \quad$ Yılmaz, s. 396.

91 European Ethical Charter on the Use of AI in Judicial Systems and Their Environment: https://rm.coe.int/ethical-charter-en-for-publication-4-december-2018/16808f699c, (E.T:07.05.2021). 
İlkeler ilk olarak yapay zeka araçlarının teknik tasarımının önemini altını çizmektedir. Burada teknik tasarım insan hakları ve yasal çerçeveye uyumlu olmalıdır. Bu nedenle teknik tasarım sürecinde etik kurallar doğrudan dahil edilmelidir. Robot hakim bakımından düşünülecek olursa tasarım ve programlama sürecinde başta hakimler, avukatlar olmak üzere hukuk dünyasında aktif rol oynayan birçok meslek grubu ve başta mühendisler olmak üzere yazılım aşamasında görev alan teknik meslek grupları arasında geniş işbirliğini gerçekleştirmelidir. Çünkü her ne kadar temelde yapay zeka yazılımları bir çıktı sunsa da bu çıktılar insan tasarımcısı tarafından eklenen girdiler üzerine inşa edilmiştir.

Yine etik ilkelerden biri olan şeffaflık ilkesi bu yapay zeka yazılımları bakımından uygulamada bazı sorunları beraberinde getirmektedir. Her ne kadar karar verme sürecinde bir hesap verilebilirlik ve şeffaflık hedeflense de, özel şirketlerin sahip olduğu haklardan ötürü ortaya bir fikri mülkiyet sorunu çıkmaktadır. Çünkü yapay zeka algoritmaları, şeffaf bir şekilde inşa edilmiş olsa bile, doğrudan özel şirketler tarafından tasarlanmıştır. Bu nedenle şirket hissedarlarından/ortaklarından başka kimseye veya devlet otoriterlerine doğrudan hesap verme yükümlülüğü altında değillerdir. Ayrıca yazılım kodlarının şeffaflık sağlamak adına tamamen açıklanması güvenlik açıklarının tespit edilebilirliği, sömürülme, manipüle edilme ihtimali veyahut diğer kullanıcıların dolandırılmasına yönelik hilelerin tanımlanmasının önüne geçilmesi adına tavsiye edilmemektedir ${ }^{92}$.

Burada yine doktrinde şirketlerin bu denli kapalı kutu olarak geliştirdiği yapay zeka tahmin algoritmalarının yargıdaki etkisi düşünülünce bir lobicilik hareketi olabileceği ve bu şirketlerin kendi politikalarının ve menfaatlerinin de yargılamanın bağımsızlığını etkileyebileceği ifade edilmektedir ${ }^{93}$.

Yine bu süreç siyasi ve demokratik kararlardan ve halkın iradesinden uzaktır. İşte bu noktada yapay zeka tahmin algoritmaları kullanılarak robot hakim tarafından verilen kararın denetimi bakımından ciddi bir etik sorun doğmaktadır. Çünkü algoritmalar, insan kapasitesinin ötesine geçen bir dizi mantıksal sürece sahiptir. 'Geleneksel' dijital teknolojiler için uygulanan klasik hesap verebilirlik uygulamaları, yani yazılım kodlarını yasal koda karşı kontrol etmek ve yazılım geliştiricileri ve sahiplerinin işleyişleri için sorumlu olan yazılım geliştiricilerini ve sahiplerini sorumlu tutma yaklaşımı

\footnotetext{
Contini, s. 14.

Özparlak, Başak Ozan: "OTOMATIKK HUKUK: Hukuk Sisteminde ve Mesleğinde Yapay Zeka”, academia.edu/45573817/OTOMATIK_HUKUK_Hukuk_Sisteminde_ ve_Mesleğinde_Yapay_Zeka,(E.T:04.05.2021).
} 
yapay zeka algoritmaları bakımından uygulama alanı bulamaz. Yukarıda detaylı bir şekilde açıkladığımız üzere yapay zeka sistemlerinin istikrarlı bir yazılım kodları bulunmamaktadır. Makine öğrenimi, derin öğrenme ve sinir ağları, yazılımın özerk ve yinelemeli değişiklikleri beraberinde getirmektedir. Sonuç olarak, hesap verebilirlik sorunu geleneksel teknolojilerden daha zordur bir hal almaktadır ${ }^{94}$.

Şeffaflık ve hesap verilebilirlik sorununun önüne geçilebilmesi için öncelikle robot hakim uygulamasının kullanılması için bir yasal izin/resmi makamlar veya otoriteler tarafindan verilen bir onay mekanizmasının getirilmesi gerektiği ifade edilmektedir. Bu şekilde onay/izin sürecinde "açılabilir" yazılım kodları sayesinde belirli kurum/kuruluşlarla sınırlı bir paylaşım yapılarak analiz edilecek; algoritmanın kanundan kaynaklanan yükümlülüklere uygunluğu ve temel hak ve özgürlüklere ne derece saygilı olduğu tespit edilebilecektir. Burada kurum veya kuruluş bakımından alternatif bir seçenek, Avrupa Konseyi İnsan Hakları Ofisi tarafından önerildiği gibi, kanunda düzenlenen bağımsız bir organa bu denetim görevinin verilmesidir. $\mathrm{Bu}$ durumda, yazılım kodlarının açıklanması, sistemi değerlendirecek bir uzman grubuyla sınırlı olacak ve fikri mülkiyet hukuku anlamında ortaya çıkabilecek sorunların önüne geçilebilecek ve algoritma yaratıcılarının mağduriyetinin önüne geçilebilecek, istenmeyen manipülasyon veya tahrif sonuçları doğmamış olacaktır. Çünkü uygulamada kullanıcılar arka planda algoritmanın hatalı olabileceği ihtimalini akıllarına bile getirmemektirler. Hal böyle iken bu hususların kullanım aşamasında hatalar ortaya çıkması beklenmeden uygulamacıların kullanımına sunulmadan bir denetimden geçirilmesi gerekmektedir ${ }^{95}$.

\section{B. Avrupa Birliği Yapay Zeka Tüzüğü Tasarısı}

Robot hakimler ile ilgili önem arz eden bir diğer uluslararası belge 14 Nisan 2021'de yayımlanan Avrupa Birliği Yapay Zeka Tüzüğü Teklifi (Regulation of the European Parliament and of the Council Laying Down Harmonised Rules On Artificial Intelligence (Artificial Intelligence Act) and Amending Certain Union Legislative Acts) dir ${ }^{96}$. Temelde 69 madde ve $8 \mathrm{ek}$ maddeden oluşan bu kapsamlı belge çalışmamız bakımından büyük önem arz etmektedir. İfade etmek gerekir ki tüzük tasarısı başta Aralık 2020

\footnotetext{
94 Contini, s. 14.

95 Contini, s. 14-15.

96 https:/digital-strategy.ec.europa.eu/en/library/proposal-regulation-laying-downharmonised-rules-artificial-intelligence, (E.T:12.06.2021)
} 
yılında yayımlanan "CAHAI" ilkeleri ve Şubat 2020 yılında yayımlanan "White Paper" ile büyük benzerlikler barındırdığı için birçok uluslararası belge ile uyum içerisinde olduğu görülmektedir.

$\mathrm{Bu}$ kapsamlı belgede yapay zekaya ilişkin hukuki çerçevenin nasıl çizileceğine dair önemli açıklamalar yer almaktadır. Tüzük taslağının birinci maddesi gereğince; üye devletlerin yapay zeka sistemlerinin üretilmesi, pazarlanması ve kullanmasına ilişkin bazı kurallar getirmeyi ve tüzüğe uygun olduğu belirlenen yapay zeka sistemlerinin üretilmesi, pazarlanması ve kullanımı süreçlerinde zorluk çıkarılmaması için gerekli korumanın sağlanmasını, yine üretim, pazarlama ve kullanma süreçlerinde uygulanacak hukuk kuralları için genel bir çerçevenin ortaya koyulmasını ve bu şekilde bir birlik sağlanması temelde amaçlanan hususlardır. Burada yapay zeka bakımından getirilen öneriler yapay zeka sistemlerinin risk derecelerine göre yapılan bir ayrım ile ortaya konulmuştur. Düşük riskli, sınırlı riskli, yüksek riskli ve kabul edilemez riskli olmak üzere dört temel grup oluşturulmuş ve her bir gruba ilişkin örneklemeler, önlemler ve yaptırımlar öngörülmüştür.

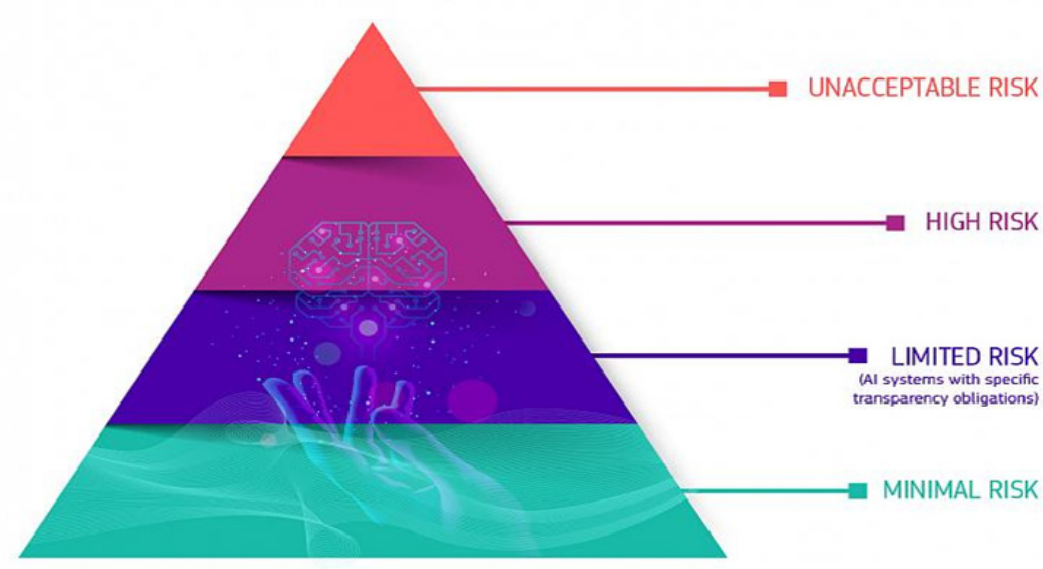

-Şekil 2-97

Çalışma konumuzu oluşturan robot hakimlerin ise aslında yüksek risk grubunda olduğu görülmektedir. Yüksek risk grubunda yer alan yapay zeka

$97 \mathrm{https}: / /$ www.euronews.com/2021/04/21/the-higher-the-risk-the-stricter-the-rulebrussels-new-draft-rules-on-artificial-intellige, (E.T:13.06.2021). 
sistemleri; veri ve veri yönetişimi, dokümantasyon ve kayılt tutma, şeffaflık ve kullanıcılara bilgi sağlanması, insan gözetimi, sağlamlık, doğruluk ve güvenlik konularına ilişkin taslakta öngörülen yükümlülüklere uyulması ve ön bir değerlendirmeye(denetime) tabi tutulması halinde kullanılabilecektir.

Bu yükümlülükler ise genel olarak; pazarlama sürecinden önce ve sonra taslakta öngörülen yükümlülüklerin yerine getirilmesi, pazarlama sürecinden sonra da uyumluluğunun denetlenmesi (bu denetim yapay zekanın sahip olduğu olas1 risklerin önceden değerlendirilmesi ve tespit edilmesi, pazarlama sürecinden sonra gerek kullanıcı gerek üçüncü kişilerden gelen veri ve analizlere göre yine risk değerlendirilmesi anlamına gelmektedir), bu risk grubunda üretilecek yapay zeka yazılımlarının veri tabanlarına kaydının sağlanması (bu şekilde yapay zeka tarafından kullanılan büyük veri yığınlarının sonradan denetlenebilmesi sağlanacak böylelikle şeffaflık ilkesi daha etkin bir şekilde uygulama alanı bulabilecektir.) ve CE işareti uygulanarak CE standardı sağlanmasıdır.

Yükümlülüklere bütüncül bir şekilde bakıldığında "Yargılama Sisteminde Yapay Zeka Kullanımına Dair Etik Şart" ile de büyük bir uyum içerisinde olduğu ve o dönem ortaya atılan önceki bölümde de detaylı bir şekilde değindiğimiz endişelerin önüne geçmek için öngörülen yükümlülüklerin elverişli olduğu görülmektedir. Bu yükümlülüklerin eksiksiz bir şekilde yerine getirilmesi halinde bu risk gurubundaki yapay zeka yazılımları uygulama alanı bulabilecektir.

Taslakta Başlık III, Bölüm 1, Madde 6 gereğince yüksek risk grubu kendi içerisinde;

皿 Uyum değerlendirmesine tabi olan ürünlerin güvenlik bileşeni olarak kullanılması amaçlanan yapay zeka sistemleri

国 Ek-III’te açıcça listelenen temel haklara etki eden diğer bağımsız yapay zeka sistemleri olmak üzere ikiye ayrılmıştır.

İfade etmek gerekir ki Ek-III’te yer alan yüksek riskli yapay zeka sistemleri, riskleri zaten gerçekleşen veya yakın gelecekte gerçekleşmesi muhtemel olan sınırlı sayıda yapay zeka sistemlerini içermektedir. Listenin ortaya çıkan kullanımlara ve yapay zeka uygulamalarına uyarlanabilmesi için Komisyon, bir dizi kriter ve risk değerlendirme metodolojisi uygulayarak bu listeyi genişletebileceğini ayrıca belirtmiştir. 
EK- III'ün kolluk güçlerince kullanan 6. başlıkta yer alan yüksek riskli yapay zeka sistemleri şu şekildedir:

(a) gerçek kişilerin bireysel risk değerlendirmelerini yapmak için veyahut gerçek bir kişinin suç işlemesi veya yeniden suç işlemesi riskini veya suçların potansiyel mağdurları için riski değerlendirmek amacıyla kolluk kuvvetleri tarafından kullanılması amaçlanan yapay zeka sistemleri,

(b) Kolluk kuvvetleri tarafindan yalan makinesi ve benzeri araçlar olarak kullanılması veya gerçek bir kişinin duygusal durumunu tespit etmek için kullanılması amaçlanan yapay zeka sistemleri,

(c) Madde 52'de(3) belirtildiği gibi derin sahteciliği tespit etmek için kolluk kuvvetleri tarafindan kullanılması amaçlanan yapay zeka sistemleri,

(d) Suçların soruşturulması veya kovuşturulması sırasında kanıtların güvenilirliğinin değerlendirilmesi için kolluk kuvvetleri tarafından kullanılması amaçlanan yapay zeka sistemleri,

(e) 2016/680 sayılı Direktifin (AB) 3(4) maddesinde belirtilen gerçek kişilerin profillemesine dayanan gerçek veya potansiyel bir suçun oluşumunu veya tekrarını tahmin etmek veya kişilik özelliklerini ve özelliklerini veya gerçek kişilerin veya grupların geçmiş suç davranışlarını değerlendirmek için kolluk kuvvetleri tarafından kullanılması amaçlanan yapay zeka sistemleri,

(f) Suçların tespiti, soruşturulması veya kovuşturulması sırasında (AB) 2016/680 sayılı Direktifin 3 (4) maddesinde belirtilen gerçek kişilerin profillemesi için kolluk kuvvetleri tarafindan kullanılması amaçlanan yapay zeka sistemleri,

(g) Gerçek kişilerle ilgili suç analitiği için kullanılması amaçlanan yapay zeka sistemleri, kolluk kuvvetlerinin bilinmeyen kalıpları tanımlamak veya verilerdeki gizli ilişkileri keşfetmek için farklı veri kaynaklarında veya farkl1 veri formatlarında bulunan karmaşık ilgili ve ilgisiz büyük veri kümelerini aramasina izin veren yapay zeka sistemleridir.

Listenin 8. başlığında ise adalet ve demokratik süreçlerin yönetiminde kullanılan:

(a) Gerçeklerin ve hukukun araştırılması ve yorumlanmasında ve yasanın somut bir gerçekler kümesine uygulanmasında bir yargı otoritesine yardımcı olmayı amaçlayan yapay zeka sistemleri yüksek risk grubuna örnek olarak gösterilmiştir.

Listede yer alan 8. başlı̆̆ın doğrudan; 6. başlıkta yer alan diğer örneklerin ise dolaylı olarak robot hakimleri oluşturan yapay zeka uygulamaları ile 
benzerlik içerdiğini söylemek hatalı olmayacaktır. Hal böyle iken şu an kullanilan veyahut gelecekte uygulanacak olan robot hakim yapay zeka uygulamaları yüksek risk barındırdığı için taslakta yer alan yükümlülüklere tabi olacaktır.

Bir diğer önem arz eden husus; Yargilama Sisteminde Yapay Zeka Kullanımına Dair Etik Şartlarda da üzerinde durduğumuz şeffaflık ve kapalı kutu sorununun çözümlenmesi adına tasarının IV. başlığının 52. maddesinde düzenlenen şeffaflığa ilişkin yükümlülüklerdir. Bu yükümlülükler değinecek olursak:

1. Sağlayıcılar, gerçek kişilerle etkileşime girmeyi amaçlayan yapay zeka sistemlerinin, koşullar ve kullanım bağlamından yapay zeka olduğu belli değil ise, gerçek kişilerin bir yapay zeka sistemi ile etkileşime girdikleri konusunda bilgilendirilecek şekilde tasarlanmasını ve geliştirilmesini sağlayacaktır. Bu yükümlülük, suçları tespit etmek, önlemek, araştırmak ve kovuşturmak için yasalarca yetkilendirilmiş yapay zeka sistemleri için geçerli değildir, ancak bu sistemler halkın suç bildirim bakımından mevcut değildir.

Görüldüğü üzere gerçek kişilerin muhatabının bir yapay zeka olduğunu bilmek hakkı açık bir şekilde ortaya konulmuş fakat suçlulukla mücadele ve suçun aydınlatılabilmesi bakımından tasarıda bir istisna öngörülmüştür.

2. Bir duygu tanıma sistemi veya biyometrik bir kategorizasyon sistemi kullanıcıları, sistemin çalışması hakkında sisteme maruz kalan gerçek kişileri bilgilendirecektir. Bu yükümlülük, kanunların suçları tespit etmesine, önlemesine ve soruşturmasına izin verilen biyometrik kategorizasyon için kullanılan yapay zeka sistemleri için geçerli değildir.

3. Mevcut kişilere, nesnelere, yerlere veya diğer varlıklara veya olaylara önemli ölçüde benzeyen görüntü, ses veya video içeriği üreten veya manipüle eden ve yanlış bir şekilde bir kişiye otantik veya doğru ('deep fake') görünen bir yapay zeka sisteminin kullanıcıları, içeriğin yapay olarak oluşturulduğunu veya manipüle edildiğini açıklayacaktır. Ancak;

Birinci alt paragraf kullanımı söz konusu ise (suçları tespit etmek, önlemek, araştırmak ve kovuşturmak için yasalarca yetkilendirilmiş yapay zeka sistemleri hali)

İfade özgürlüğü hakkının ve AB'nin Temel Haklar Şartı'nda koruma altına alınmış sanat ve bilim özgürlüğü hakkının kullanılması için gerekli bir hal söz konusu ise bu yükümlülük söz konusu olmayacaktır. Fakat bu hallerde dahi üçüncü kişilerin hak ve özgürlükleri için gerekli korumanın sağlanması gerekmektedir. 
Son olarak ifade etmek gerekir ki tüzük tasarısında yer verilen yükümlülüklerin eksiksiz bir şekilde yerine getirilmemesi halinde robot hakim için gerekli olan yapay zeka uygulamaları veyahut önceki bölümlerde bahsi geçen tahmin uygulamalarının (failin tekerrür olasılığının tahmin eden yapay zeka yazılımları gibi) üretimi, pazarlaması veyahut kullanımı söz konusu olamayacaktır. Nitekim taslağın "Gizlilik ve Cezalar" isimli 10. başlığının 71. maddesi gereğince;

Yapay zeka sisteminin, 5.ve 10. maddelerde belirtilenler dışında, taslak kapsamındaki herhangi bir gereklilik veya yükümlülüğe uyulmaması halinde kural olarak 20000000 Euro'ya kadar idari para cezasi uygulanacaktır. Ancak gereklilik veya yükümlülüğe uymayanın bir şirket olması halinde, bir önceki mali yıl içindeki toplam dünya çapında yıllık cirosunun \%4'üne kadar olan miktar tespit edilerek hangisi daha yüksekse o miktarda idari para cezası uygulama alanı bulacaktır. Bununla birlikte 10 . maddede yer alan veri yönetişimine ilişkin bir ihlal söz konusu olur ise kural olarak 30000000 Euro'ya kadar idari para cezası uygulanacaktır. Ancak gereklilik veya yükümlülüğe uymayanın bir şirket olması halinde, bir önceki mali yıl içindeki toplam dünya çapında yıllık cirosunun \%6'sına kadar olan miktar tespit edilerek hangisi daha yüksekse o miktarda idari para cezası uygulama alanı bulacaktır.

\section{ROBOT HAKIM UYGULAMASININ SONUÇLARI}

Bu bölüme kadar izah edilen hususlar doğrultusunda çalışmanın sonucunu ortaya koymak adina; robot hakim fikrinin uygulamaya geçirilmesi halinde ortaya çıkabilecek olası olumsuz ve olumlu sonuçlar ayrı ayrı ele alinacak olursa:

Robot hakim karar verme sürecinde ortaya çıabilecek bazı sorunlardan/hatalardan ötürü “önyargıll” kararlar verebilecektir.

Yapay zeka araçlarını yargısal süreçlerde kullanmak elbette birçok açıdan avantaj sağlamaktadır. Fakat unutulmamalıdır ki, insanların bu muazzam veri miktarlarını ve mantıksal süreçleri gerçekten kontrol etmesi mümkün değildir. İşte bu noktada robot hakimin vereceği kararların güvenilirliği sorunu ortaya çıkacaktır. Nitekim veri bilimcilerin son zamanlarda yaptıkları çalışmalarda yapay zeka tahmin teknolojilerinin gerçekten adil ve objektif olmadığ1 sonucuna ulaşılmıştır. Önceki bölümlerde COMPAS örneğinde olduğu gibi ceza türünün ve miktarının belirlenmesinde ırksal, cinsiyet bazlı önyargılar belirleyici olabilecektir. Örneğin; algoritma posta kodu ve ikametgah bilgilerini dikkate alarak Afro-Amerikan bireylerin işlediği suçlar 
bakımından daha ağır cezalar öngörebilir. Yine 23 Mart 2016 yılında Microsoft tarafindan twitter üzerinden tanitilan yapay zeka chatbotu TAY (Talking About You) lansmandan 16 saat sonra ırkçı, saldırgan ve şiddet içerikli twitler atması bu duruma örnek gösterilebilir ${ }^{98}$.

$\mathrm{Bu}$ tarz istenmeyen sonuçların doğmasında etkili olan husus yapay zeka tasarımcısı tarafından verilen "başarı" tanımına yapay zekanın sıkı sıkıya bağlı olması ve somut olayda yer alan önemli değişkenleri göz ardı etmesidir. Örneğin; olayda yer alan bir önyargıyı ya da sübjektif bir nitelendirme nedeniyle yanlış bilgiyi yok sayma konusunda hataya düşebilirler. Çünkü yapay zeka aslında burada "matematiğe gömülü bir görüş" ortaya koymaktadır. Bu yüzden gerçekten adil ve nötr olamayacağı gibi bir insan hakim yerine de kullanılamayacaktır ${ }^{99}$.

Bir başka deyişle bir insan hakim kadar iyi bir yapay zeka algoritmasının geliştirilememesinin nedeni algoritmanın yerine getirmesi gereken entelektüel görevlerin çok karmaşık olması değil insan hakimin; araştırma yapabilme, dil, mantık yürütme, yaratıcı problem çözme ve sosyal beceriler gibi birden çok karışık becerilere sahip olması gerekliliğidir. Elbette yakın gelecekte bu becerilerin ayrı ayrı algoritmalar tarafından kusursuz bir şekilde yerine getirilmesi mümkün olabilir. Çünkü algoritmalar temelde genellikle belirli bir amaç için üretilmektedir. Fakat burada önemli olan bu becerilerin ayrı ayrı değil bir arada algoritmada bulunmasıdır ${ }^{100}$.

\section{uzaktır.}

Robot hakim karar verirken toplum vicdanı kavramından

Burada unutmamak gerekir ki toplumu oluşturan bireyler bir ceza yargılamasında hakimin vicdani kanaati için bir mücadele verdiğini ve en önemlisi bunu gerekçelendirebildiğini görmek arzusu vardır. Nitekim duruşmaların kanunda görülen istisnai haller dışında aleni olması ve vatandaşın istediği zaman yargılamayı şeffaf bir şekilde takip edebilmesi bunun bir göstergesidir ${ }^{101}$. Hal böyle iken robot hakimin toplum vicdanı kavramından uzak olması toplumsal adalet ve barışın tesisi hususunda kendinde bir sorumluluk hissetmemesi anlamına gelecektir. Bu durum da robot hakimlerin toplumsal olarak kabulüne engel olacak başat nedenlerden biri olacaktır.

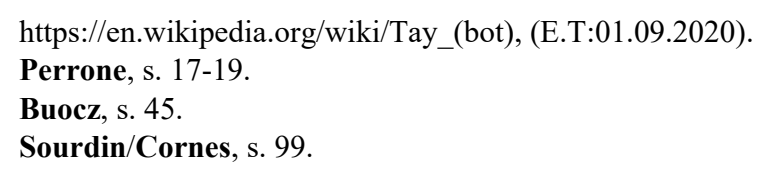




\section{且 Robot hakimin “takdir yetkisini” nasıl kullanacağı başka bir sorundur.}

Robot hakim kendisine verilen bilgiye benzer bir bilgi söz konusu ise faydalı ve isabetli bir şekilde bu bilgiyi analiz edebilecektir. Çünkü makine öğrenmesiyle desenleri keşfetme ve etkili bir genelleme yapabilmek için kendisine önceden verilen örnek davaların boyutu yeterli olmayabilecek$\operatorname{tir}^{102}$. Bir başka deyişle robot hakim somut olay ile kendisine verilen verilerde bir benzerlik ya da bağlantı yakalayamaz ise somut olay özelinde takdir hakkı kullanamayacaktır. Çünkü bu makine öğrenmesinin verdiği yeteneğin çok daha ötesinde her zaman yeni bir öğrenme örüntüsünü gerektirmektedir. Burada aslında robot hakimden beklenen bir insan hakim gibi iç görüye sahip olmasidır.

Şu an robot hakimlerin bu iç görüye sahip olmaması nedeniyle ceza yargılamasında hakim olarak görev alması mümkün görünmemektedir ${ }^{103}$. Yargılama faaliyeti ispat ve hükmün verilmesiyle birlikte bir bütün niteliğindedir ${ }^{104}$. İspat kurumu nispi bir nitelik taşımakta olup delillerin hakim tarafından serbestçe değerlendirilmesi ve en önemlisi vicdani kanaat sisteminin mevcut olması bu soruna temel gerekçeler olarak gösterilebilir.

Hakimin vicdani kanaati manevi bir olgu olup delillerden tamamen bağımsız bir olgu değildir. Hakim delilleri inceleyerek vicdanına göre serbest bir kanaate vardığ için hakimin vicdani kanaati somut olayda yer alan delillerden bağımsız bir şekilde düşünülemeyecektir. Burada hakim yalnızca mantıksal bir anlayışla hareket etmemekte aynı zamanda duygusal bir etkinliği de barındıran bir mesleği tecrübeden de istifade etmektedir. Hal böyle iken hakimin vicdani kanaati bilimsel olarak tartışılabilir olup matematiksel olarak bir kesinliğe de sahip değildir. Bununla birlikte somut olayda yer alan delillere ve olgulara dayandırılarak gerekçelendirilebildiği için keyfilikten de ayrılmaktadır ${ }^{105}$. Kaldı ki gerekçeli karar bir hukuk devletinin vazgeçilmezi olduğundan yapay zekalı hakimin ulaştı̆̆ kanaati bir gerçek kişi gibi gerekçelendirmesi mümkün olmayacaktır. Çünkü yapay zekanın karar verme sü-

102 Sourdin, s. 1128

103 İçer/Buluz, s. 32.

104 Dülger, Murat Volkan: "Günümüz Yapay Zeka Teknolojisi ve 'Robot Yargıç/Avukat' Gerçeği: Mesleğimiz Elimizden Gidiyor Mu?”, HPlus Dergisi, Say1:5, Ocak 2018, s. 9, https://www.researchgate.net/publication/322789785, (E.T:12.09.2021).

105 Özbek, Veli Özer: "Ceza Muhakemesinde Hakimin Vicdani Kanaati”, Hukuk Felsefesi ve Sosyolojisi Arkivi, 16. Kitap, İstanbul 2007, s. 284-287; Doğan, s. 350. 
reci denetlenemediğinden bir kararı neden veya nasıl verdiğini açıklamayacaktır.

Örneğin; Türk Ceza Kanunu'nun 62. maddesinin ikinci fikrasında yer alan "failin geçmişi, sosyal ilişkileri, fiilden sonraki ve yargılama sürecindeki davranışları, cezanın failin geleceği üzerindeki olası etkileri” gibi takdiri indirim nedenlerinin robot hakim tarafından uygulanabilmesi mümkün değildir. Bu takdiri indirim nedenlerinin bir şekilde algoritmik olarak tespiti mümkün olsa dahi yine aynı hüküm nedeniyle robot hakimin hangi takdiri indirim nedenini tercih ettiğini gerekçeli bir şekilde kararda ortaya koyması gerekecektir.

Yine insan hakimin vicdani kanaati bir bakıma ikna olup olmamasını da içerdiğinden ceza muhakemesi hukukuna hakim ilkelerden biri olan "kuşkudan sanık yararlanır" gibi vicdan ve irade kavramlarından bağımsız düşünülemeyecek bir ilkenin robot hakim tarafından nasıl uygulanacağı da bir muammadır. Çünkü bu ilkenin uygulama alanı bulması için oluşması gereken hakimin kanaati; iddia ve savunmanın şekillendirdiği somut olaya ilişkin anlık bir değerlendirme olmayıp akıl ve duyguların iç içe geçtiği bütüncül bir değerlendirmedir ${ }^{106}$.

$\mathrm{Bu}$ noktada yine önceki bölümlerde uzunca üzerinde durulduğu üzere kapalı kutu olan yapay zekanın böyle bir karar verme sürecini nasıl gerçekleştirdiğini tespit etmek şu an için mümkün değildir. Bu nedenle doktrinde yapay zekalı hakimlerin ancak Ticaret/İcra Mahkemelerinde mükerrer işleri yapabileceği ifade edilmektedir ${ }^{107}$.

Q Robot hakimin temelini oluşturan tahmin algoritmalarının yargıda kullanılması yalnızca danışma niteliğiyle sınırlı tutulsa dahi burada hakimin tarafsızlığı ve bağımsızlı̆̆ ve adil yargllanma hakkı noktasında sorunlar ortaya çıkacaktır. Şöyle ki;

Uygulamada, yapay zeka sistemleri tarafindan öncelikle veriler arasinda istatistiksel korelasyonlar oluşturulur ardından istatistiki bilgiler paketlenir, özetlenir ve karar verme görevlerini 'desteklemek' için hakime teslim edilir. $\mathrm{Bu}$ süreç içerisinde yukarıda COMPAS örneğinde anlatıldığ 1 üzere algoritmanın önyargılı veyahut hatalı karar vermesi mümkündür. $\mathrm{Bu}$ nedenle örneğin; tekerrür hesabı yapan bir algoritmanın sanığın kefalet duruşmasından önce tekerrür olasılığını çok yüksek hesaplayıp mahkeme ile paylaştığı bir durumda hakim bu oranın etkisinde kalmadan sanığın yine

106 Doğan, s. 349-350.

107 Bacaksız/Sümer, s. 265. 
kefaletle salıverilmesine karar verebilecek midir? Sanığın salıverilmesi ve suç işlemesi halinde durum nasıl değerlendirilecektir? Veyahut tam tersi bir olasılıkta algoritmanın tekerrür olasılığını çok düşük hesaplamasına karşın hakim bu durumu görmezden gelip gözaltı/tutukluluk halinin devamina karar verebilecek midir?

Tüm bu olasılıklarda gördüğümüz üzere hayatın olağan akışında hakimin algoritmanın sunduğu olasılıklardan tamamen bağımsız bir şekilde hüküm tesis edemeyeceği ve etkisinde kalacağ karar mercii değil de danışman görevini üstlendiği bir pozisyonda dahi hakimin tarafsızlığı ve bağımsızlığına gölge düşecektir. Kaldı ki burada şeffaflık bakımından yetersiz ve bir sorumluluk atfedilemeyen bir karar mekanizması olduğu görülmektedir. Hal böyle iken böyle bir mekanizmanın karar üzerindeki etkisi ciddi sorunları beraberinde getirmektedir. Mahkeme tahmin teknolojilerinin karar alma süreçlerinin denetleyemeyeceği için adil yarg1lanma hakkı da ihlal edilmiş olacaktır ${ }^{108}$.

Q Robot hakim ana karar mercii olmayıp araç olarak yargılamada destekleyici bir rol üstlendiğ i halde insan hakimin yargı yeteneği ve yeterliliğine ilişkin kamuoyunun algısı etkilenebilecektir.

$\mathrm{Bu}$ durumda iki ihtimal söz konusu olabilecektir. İlk durumda toplum bunu hakimin özgüven belirtisi olarak yorumlayıp tam tersi yargı yükünü hafifletmek ve verimliliği arttırmak için yardımcı bir yol olarak görebilir. Bir başka ihtimal ise kamuoyunun bunu hakimin yargı yeteneğinin yetersizliğ olarak yorumlanıp yargının muhtaç durumda olduğu izlenimine kapılacağ gibi gerçek kişilerin yargıya yabancılaşması da söz konusu olabilecektir ${ }^{109}$. Toplumun yarg1 organlarına güveni ve inancı adaletin tesisi bakımından son derece önem arz eden bir husustur.

昌 Bir diğer sorun ilk derece yargılamasından olağan kanun yolları olan istinaf, temyiz aşaması ve olağanüstü kanun yolları aşamasına kadar robot hakim ile insan hakimin hangi kararlart vereceği, hangi mahkemelerde çalışacağ ve en önemlisi farklı derecelerde farklı hakimlerin olması halinde uyum süreçlerinin nasıl denetleneceği önemli tartışmaları beraberinde getirecektir.

Çünkü burada şeffaflığın ve güven ilkesinin bir gereği olarak iç denetim tek başına yeterli olmayıp beraberinde bir dış denetimi de gerekli kıla-

108 Contini, s. 13; Perrone, s. 15; Yılmaz, s. 406.

109 Buocz, s. 54-55; Re/Solow-Niederman, s. 276; Bacaksız/Sümer, s. 265. 
caktır $^{110}$. Yine bu kademelendirme sürecinde tamamen insan hakimden oluşan bir yargı birimi ile tamamen robot hakimden oluşan bir yargı birimi arasında bağlantının nasıl kurulacağı önem arz edecektir. Çünkü ilk derece mahkemesi bir robot hakimden oluşuyor ise bir sonraki yargı basamağının insan hakimden oluşması gerekecektir. Burada ilk derece mahkemesinde robot hakimin verdiği kararı temyiz ya da istinaf kanun yolu evresinde bir insan hakimin denetlemesi gerekecektir. $\mathrm{Bu}$ bir nevi filtreleme sistemi getireceği için daha isabetli olacaktır. Fakat bu kez bu denetlemenin sınırları da belirlenmelidir. Burada insan hakim yalnızca kararı $\mathrm{m} 1$ denetleyecektir? Yoksa kararı vermeyi sağlayan algoritmayı da denetlemesi gerekecek midir? ${ }^{111}$ Her ne kadar robot hakim uygulamalarının şu an uyuşmazlık çözümlerinde giriş seviyesinde ya da yardımcı rolünde kullanıldığ görülse de pek uzak olmayan bir gelecekte bu sorulara yanıt bulunması gerekecektir.

昌 Robot hakim uygulamasının getirildiği bir düzende kararı veren robot hakim mi olacaktır? Robot hakimin vereceği karar bakımından yasal sorumlu kim olacaktır? Robot hakim uygulamasına geçildiğince öncelikle bu "yetki/sorumluluk sorunu”"nun açıklı̆g kavuşturulması gerekecektir.

Bir başka deyişle robot hakimin karar verdiği bir yargılamada hukuki otoritenin kim olacağ konusu olacaktır. Başta robot hakimde kullanılan yapay zeka tahmin teknolojisinin programlayıcısı olmak üzere, insan hakim, eğer otonomluk söz konusu ise robot hakim, robot hakim uygulamasinda izin veren siyasi/idari otoriteler, denetlemekle yükümlü tutulan gerçek ya da tüzel kişiler gibi birçok sorumluluk sahibi söz konusu olabilecektir. Bu tartışma robot hakimin verdiği karara karşı bir itiraz kanun yolunun oluşturulması ve en önemlisi bir denetim mekanizmasının oluşturulabilmesi adına büyük önem taş1maktadır ${ }^{113}$. Denetim mekanizmasının bulunmadığı bir halde örneğin; insan hakimin olası hataları düzelten bir güvenlik ağı gibi işlevinin olmadığı bir yarg1 düzeninde toplum robot hakimin yargıdaki görev ve rolünü de benimsemeyip red edecektir ${ }^{114}$.

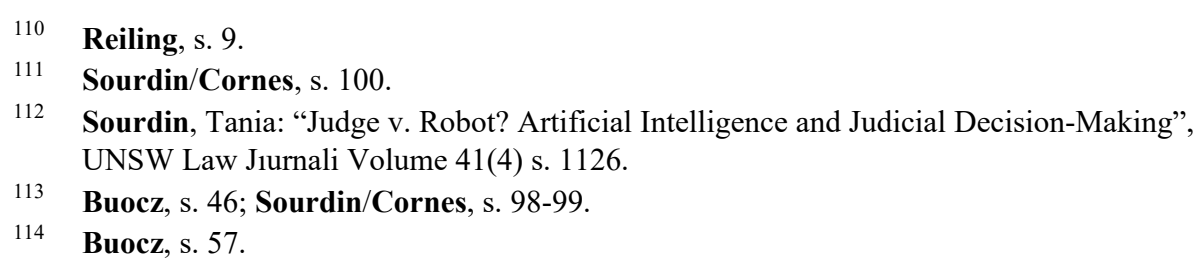




\section{品san hakim ile robot hakimin ayn davada farklt fikirde olmast halinde uyuşmazlık nasıl çözülecektir?}

Böyle bir durumda temelde üç olasılık söz konusudur: İnsan hakim hatalı karar vermiş olabilir, robot hakim hatalı karar vermiş olabilir veyahut somut olayın özelliklerinden kaynaklı olarak birden fazla yoruma ulaşılmış olabilir.

Doktrinde bir görüşe göre; burada düz(basit) ya da komplike dava ayrımının yapılması gereklidir. Burada basit davadan kasıt hakimin genel terimleri yorumlamaya ihtiyaç duymadığı veya örneklerin tanınmasının sorunsuz ya da otomatik bir şekilde yapılabileceği yani hukuk kurallarının uygulanabilirliğine ilişkin genel bir anlaşma halinin olduğu davalardır. Komplike davalar ise; yasalara göre belirsiz ya da bilinmeyen durumları içeren delile dayalı akıl yürütmenin önemli bir etkiye sahip olduğu davalardır. Basit davalar bakımından yapay zekalı hakime sınırlı bir yargı yetkisi verilerek bariz hata yapma olasılıkları karşısında insan hakimin bir güvenlik ağı olarak kullanıldığı bir olasılıkta hızlı ve verimli bir karar verme süreci mümkün olabilir. Fakat aynı husus komplike davalar bakımından geçerli olmayıp yapay zekanın sınırlayıcı özellikleri nedeniyle yetersiz kalmaktadır ${ }^{115}$.

Kanaatimizce burada bu şekilde bir ayrım yapmak isabetli değildir. Bir uyuşmazlığın/hukuka aykırılığın yargılama süreci içerisinden basit halden komplike hale de evrilmesi hayatın olağan akışında bittabi mümkündür. Kaldı ki bu şekilde yapılan bir ayrımın objektif ve net kriterlere dayandırılması güç olup sübjektif bir perspektifi içermektedir. Bu nedenle robot hakimlerin insan hakim karşısındaki yetersizlikleri de dikkate alındığında robot hakimlerin yargıda görev aldığı bir düzende insan hakimin aralarında oluşacak bir görüş uyuşmazlığında belirleyici role sahip olması gerekmektedir.

\section{Robot hakim yargllama sürecinde süjelerle iletişim konusunda halen bir insan hakim seviyesinde değildir.}

Mahkemede tarafların kurdukları iletişim neticesinde insan onuruna uygun, duygu ve şeffaflık çerçevesinde yürütülen bir süreç bulunmaktadır. Nitekim ceza muhakemesi hukukuna da hakim olan ilkelerden biri olan meramını anlatma ilkesi ancak bu şekilde var olabilecektir. Robot hakim karş1sında sanığın ifadelerinde yer alan duyguları tanımlaması ve buna uygun yanıt vermesi mümkün olmayacaktır. Yine robot hakimin tanık dinleme tanığa soru yöneltme veyahut beyanları arasındaki çelişkiyi tespit edebilme gibi önemli hususlarda karşılıklı iletişime giremeyeceği için yetersiz kala-

115 Buocz, s. 56-57. 
cağı aşikardır. Bu durum muhakeme sürecinde ciddi sorunları da beraberinde getirecektir. $\mathrm{Bu}$ nedenle robot hakimin nerede hangi hukuk uyuşmazlıklarında kullanacağına ilişkin mutlaka bir sınırlandırma getirilmesi gerekmektedir $^{116}$.

$\square$ Robot hakimin sunulan verilerin ve algoritmanın stnırlarının ötesinde bir kapasitesi veyahut aşabilme yetisi olup olmadiğı halen şüphe barındiran bir konudur ${ }^{117}$.

Robot hakimin ceza yargılaması gibi bir alanda mahkemenin yapacağ sorguda aktif ve etkin olması gerekirken bunun kendisine verilen sinırlar çerçevesinde kalması temel birçok ilkeye aykırılık teşkil edecektir ${ }^{118}$. Aksi bir ihtimalde de yani tahmin teknolojilerinde yeni mantık yürütme sistemleri geliştirildikçe aynı tahmin kalıplarının kullanılmasına devam edilmeyebilecektir. İşte bu belirsizlik tahmin teknolojilerinin çıktı olarak sunduğu kararlarda da belirsizliği oluşturacağı için hukuk anlamında da belirsizliği ve güvensizliği beraberinde getirecektir ${ }^{119}$.

㽞 Bir diğer önemli nokta robot hakim uygulamasına geçilmesi halinde uygulanan yer ve zamana göre algoritmanın uyarlanması ve denetlenmesi gerecektir.

Hukuk dünyasında evrensel ilkeler bulunmakla birlikte her ülkenin kendine ait bir hukuk sistemi olduğu için robot hakimin üretilirken görev yapacağı ülkeye uygun olarak kanun koyucu, avukatlar, hakimler, siyasiler gibi birçok meslek grubundan kişinin üretici ve geliştiricilerle işbirliği içerisinde olmasını gerektirecektir ${ }^{120}$.

* Buraya kadar açıklanan olumsuz sonuçlara karşında bir takım olumlu sonuçlar da elbette olabilecektir. Robot hakimin kullanılması hizl çalışma kabiliyeti nedeniyle yargı yükünü hafifletebilecek ve yargılama

\footnotetext{
116 Sourdin/Cornes, s. 97; Bacaksız/Sümer, s. 265; Yılmaz, Gökhan Oğuz: "Yarg1 Uygulamasında Yapay Zekâ Kullanımı - Yapay_Zekâ Hâkim Cübbesini Giyebilecek Mi?", Adalet Dergisi, Say1:66, 2021/1, s. 405.

117 Re, Richard M./Solow-Niederman, Alicia: "Developing Artificially Intelligent Justice", 22 STAN. TECH. L. REV, 242 (2019), s. 263; Bacaksız/Sümer, s. 265.

118 Sourdin/Cornes, s. 99-100.

119 Morison J./Harkens, A., s. 9; Bacaksız/Sümer, s. 265.

120 Sourdin/Cornes, s. 101.
} 
süreçlerini kısaltabilecektir. $\mathrm{Bu}$ şekilde aynı zamanda yargıya ulaşmada verimlilik ve etkinlik artırılmış olacaktır ${ }^{121}$.

* Yine hakimin tarafsızlığı ve bağımsızlığı çerçevesinde robot hakim objektif olmak konusunda insan hakime kıyasla başarı potansiyeli yukarıda anlatılan hususlar dikkate alınarak gerekli teknolojik gelişmeler sağlanırsa daha yüksek olacaktır. Çünkü robot geçmiş veya şimdiki ilişkilere, yanlış empatiye, hayranlığa veya karar vermede diğer öznel etkilere dayanarak ilgili taraflardan herhangi birini tercih etmeksizin karar verebilmektedir. Buna karşın insan hakimin karar verme mekanizmasına bakıldığında önyargılarından ya da değer yargılarından etkilenerek karar verme sürecinde tamamen objektif davranamamaktadır. Örneğin; uygulamada hakimlerin hüküm duruşması öncesi hüküm tutanağını hazırlayarak duruşmada bunu doğrudan kullanması aslında hakimin karar verme sürecinde delilleri tartışmaktan ziyade bir takım kesin yargılarla hareket ettiği izlenimi yaratmaktadır. Çünkü hüküm mutlaka delillerin tartışıldığı aşamada ve duruşmada konuşulmalıdır. Yine kimi zaman hakimin sübjektif değer yargıları failin kusurluluğunu belirlerken etkili olmaktadır. Oysa burada kanuna göre kusurluluğun tespiti yapılmalıdır. İnsan hakimin robot hakimden farklı olarak dış etkenlerden etkilenmesi de yaygın görülen bir durumdur. Örneğin; toplumsal olaylarda basının veyahut halkın tepkisi hakimin karar verme süreçlerinde etkili olabilmektedir ${ }^{122}$.

\# Robot hakimin sunacağı bir başka avantaj yanlış hesaplamalar olmadan çalışmasıdır. Çünkü yazılım, tüm miktarların insan hatası riski olmadan hesaplanacağ 1 şekilde tasarlanmıştır ${ }^{123}$. Bu özelliği sayesinde bir insanın işleyebileceğinin çok daha üzerinde dev veri yığınlarını yanlış hesaplama riskini minimuma indirerek sistematik bir şekilde işleyebilecek ve istenilen çıktıyı sunabilecektir.

121 Contini, Francesco: "Artificial Intelligence and the Transformation of Humans, Law and Technology Interactions in Judicial Proceedings", Law, Technology and Humans, Volume 2 (1) 2020, s. 6, https://thj.qut.edu.au/, (E.T:03.05.2021).

122 Doğan, s. 316-317.

123 Nakad/Herik/Jongbloed/M.Salem, s. 64-65. 


\section{KAYNAKÇA}

Aydemir, Emrah: Weka ile Yapay Zeka, Seçkin Yayıncılık, Güncellenmiş 2. Bask1, Ankara 2019.

Aydemir, Melisa: "Yapay Zekalı Robotların Ceza Sorumluluklarının Araştırılması", Suç ve Ceza Dergisi, Sayı:4, 2018, s. 1-97.

Bacaksız, Pınar/Sümer, Seda Yağmur: Robotlar, Yapay Zeka ve Ceza Hukuku, Adalet Yayınevi, Ankara 2021.

Bostrom, Nick: Süper Zeka, Koç Üniversitesi Yayınları, İstanbul 2019.

Buocz, Thomas Julius: "Artificial Intelligence in Court Legitimacy Problems of AI Assistance in the Judiciary", Retskraft - Copenhagen Journal of Legal Studies, Volume 2, Number 1, Spring 2018, s. 41-59, https://static1.squarespace.com/static/59db92336f4ca35190c650a5/t/5a d9da5f70a6adf9d3ee842c/1524226655876/Artificial+Intelligence+in+ Court.pdf, (E.T:12.04.2021).

Calo, Ryan: "Artificial intelligence policy: a primer and roadmap", Univercity of Bologna Law Review, Cilt:3, Say1:2, 2018, s. 399-435, https://bolognalawreview.unibo.it/article/view/8670/8420, (E.T:18.08.2020).

Contini, Francesco: "Artificial Intelligence and the Transformation of Humans, Law and Technology Interactions in Judicial Proceedings", Law, Technology and Humans, Volume 2 (1) 2020, https://thj.qut.edu.au/, (E.T:03.05.2021)

Çiçekdağı, Caner: “Aristoteles'te Mantık Kavramı ve Temel Akıl Yürütme Çeşitleri”, MSKU Eğitim Fakültesi Dergisi, Cilt: 3, Sayı Nisan 2016, s. 55-63, https://www.researchgate.net/profile/Caner-Cicekdagi2/ publication/304528109_Aristoteles'te_Mantik_Kavrami_ve_Temel_Ak il_Yurutme_Cesitleri/links/5ef3330f4585153fb1b0abff/AristotelesteMantik-Kavrami-ve-Temel-Akil-Yueruetme-Cesitleri.pdf, (E.T:11.09.2021).

Çüçen, A. Kadir: Mantık, 8. Baskı, Sentez Yayıncılık, Bursa 2012.

Danziger, Shai/Levav, Jonathan/Avnaim-Pesso, Liora: "Extraneous Factors in Judicial Decisions", s. 6889-6892, www.pnas.org/cgi/doi/10.1073/ pnas.1018033108, (E.T:04.04.2021).

Doğan, Koray: Ceza Muhakemesinde Belirsizlik Kuşkudan Sanık Yararlanır İlkesi "in dubio pro reo", 2. Bası, Seçkin Yayıncılık, Ankara 2018. 
Dülger, Murat Volkan: “Günümüz Yapay Zeka Teknolojisi ve 'Robot Yargıç/Avukat' Gerçeği: Mesleğimiz Elimizden Gidiyor Mu?”, HPlus Dergisi, Say1:5, Ocak 2018, s. 4-9, https://www.researchgate.net/ publication/322789785, (E.T:12.09.2021).

Ersoy, Çağlar: Robotlar ve Ceza Hukuku, Onikilevha Yayıncılık, 4. Bası, İstanbul 2019.

Houy, Constantin/Niesen, Tim/Fettke, Peter/Loos, Peter: "Towards Automated Identification and Analysis of Argumentation Structures in the Decision Corpus of the German Federal Constitutional Court", Institute for Information Systems (IWi) at the German Research Center for Artificial Intelligence (DFKI) and Saarland University Saarbrücken, Germany, https://www.dfki.de/fileadmin/user_upload/import/6833 IEEE_DEST_2013_Houy_Niesen_Fettke_Loos-ARGUMENTUM.pdf, (E.T:05.04.2021).

Humbe, A. B./Deshmukh, P. A./Kadam, M. S.: "The Review Of Articulated R12 Robot And Its Industrial Applicationas", International Journal of Research in Engineering \& Technology (IMPACT: IJRET), Cilt: 2, Say1: 2, 2014, s. 113-118.

İçer, Zafer/Buluz, Başak: "Yapay Zekânın Ceza Muhakemesindeki Rolü ve Geleceği”, 9. Uluslararası Suç ve Ceza Film Festivali, İstanbul Üniversitesi, 2019, https://www.academia.edu/41074795/YAPAY ZEK\%C3\%82NIN_CEZA_MUHAKEMES\%C4\%B0NDEK\%C4\%B0 _ROL\%C3\%9C_VE_GELECE\%C4\%9E\%C4\%B0, (E.T:07.05.2021).

Karaduman, Tevfik: "Yapay Zeka Uygulama Alanları", Gazi Üniversitesi, Bilişim Enstitüsü, Adli Bilişim. A.B.D, https://www.academia.edu/ 16703256/Yapay_zeka_makale_09_06, (E.T:13.06.2021).

Kılıçarslan, Kara Seda: "Yapay Zekanın Hukuki Statüsü ve Hukuki Kişiliği Üzerine Tartışmalar”, Yıldırım Beyazıt Hukuk Dergisi, Yı1: 2019/20, Say1:4, s. 363-389.

Medvedeva, Masha/Vols, Michel/Wieling, Martijn: "Using machine learning to predict decisions of the European Court of Human Rights", Artifcial Intelligence and Law", 28, 2020, s. 237-266, https://doi.org/ 10.1007/s10506-019-09255-y, (E.T:05.04.2021).

Mijwill, Maad M.: "History of Artificial Intelligence", Nisan 2015, s. 1-5, https://www. researchgate. net/publication/322234922_History_of_ Artificial_Intelligence, (E.T: 05.04.2021). 
Morison, J./Harkens, A.: "Re-sEngineering Justice? Robot Judges, Computerised Courts and (Semi) Automated Legal Decision-Making", Legal Studies, 39(4), 2019, s. 618-635 https://doi.org/10.1017/ 1st.2019.5, (E.T:06.04.2021).

Nakad, Henriette/Herik, H. Jaap Van Den/Jongbloed, Anthonie/M.Salem, Abdel-Badeeh: "The Rise of the Robotic Judge in Modern Court Proceedings", ICIT 2015 The 7th International Conference on Information Technology, s. 59-67, https://www.researchgate.net/ publication/300720949, (E.T:08.04.2021).

Nilsson, Nils J.: Yapay Zeka Geçmişi ve Geleceği, 2. Bask1, Boğaziçi Üniversitesi Yayınevi, İstanbul 2019.

Özbek, Veli Özer: "Ceza Muhakemesinde Hakimin Vicdani Kanaati", Hukuk Felsefesi ve Sosyolojisi Arkivi, 16. Kitap, İstanbul 2007, s. 283287.

Özlem, Doğan: Mantık, 14. Bası, Notos Kitap Yayınevi, İstanbul 2011.

Özparlak, Başak Ozan: "İnsan-Robot Etkileşimi ve Hukuk", Hukuk Köprüsü, Cilt:16, Sayı:16, 2019, s. 195-210.

Özparlak, Başak Ozan: "OTOMATIK HUKUK: Hukuk Sisteminde ve Mesleğinde Yapay Zeka”, academia.edu/45573817/OTOMATÍK_ HUKUK_Hukuk_Sisteminde_ve_Mesleğinde_Yapay_Zeka, (E.T:04.05.2021).

Öztemel, Ercan: Yapay Sinir Ağları, Papatya Yayınc1lı, İstanbul 2012, http://papatyabilim.com.tr/PDF/yapay_sinir_aglari.pdf, (E.T:11.09.2021).

Perrone, Francesco: "The Judge of the Future: Artificial Intelligence and Justice", Judicial Ethics and Professional Conduct, Team Italy 2, Semifinal D, Themis 2019, https://www.ejtn.eu/PageFiles/17916/ TEAM\%20ITALY\%20II\%20TH\%202019\%20D.pdf, (E.T:12.09.2021).

Re, Richard M./Solow-Niederman, Alicia: Developing Artificially Intelligent Justice, 22 STAN. TECH. L. REV, 242, 2019, s. 242-289.

Reiling, A. D. (Dory): "Courts and Artificial Intelligence", International Journal for Court Administration, 11(2), 2020, s. 2-10, http://doi.org/ 10.36745/ijca.343, (E.T:04.04.2021).

Russell, Stuart J./Norvig, Peter: Artificial Intelligence A Modern Approach, Third Edition, Prentice Hall, 2010, https://www.cin.ufpe.br/ tfl2/ 
artificial-intelligence-modern-approach.9780131038059.25368.pdf, (E.T:08.08.2021).

Sourdin, Tania/Cornes, Richard: "Do Judges Need to Be Human? The Implications of Technology for Responsive Judging", Chapter in The Responsive Judge, s. 87-119, https://www.researchgate.net/publication/ 326244385, (E.T:05.04.2021).

Sourdin, Tania: "Judge v. Robot? Artificial Intelligence and Judicial Decision-Making", UNSW Law Jiurnali Volume 41(4), s. 1114-1133, https://www.unswlawjournal.unsw.edu.au/wp-content/uploads/2018/ 12/Sourdin.pdf, (E.T:12.09.2021).

Şen, Zekai: Modern Mantık, Bilge Kültür Sanat, İstanbul 2003.

Tarımcıoğlu, Halise: "Akıl Yürütme Yöntemleri ve Yapay Zekâ", IX. Mantık Çalıştayı Kitabı, Mantık Derneği Yayınları, İstanbul 2019, s. 423-433, https://mantik.org.tr/wp-content/uploads/2019/12/IX-MantikCalistayi-Kitabi.pdf, (E.T:07.05.2021).

Ünsal, Burçak: "Yapay Zeka, Robotlar, Hukuki Düzenlemeler", İstanbul Barosu Dergisi, Cilt: 93, Say1: 4, 2019, s. 64-74, https://www.doganturan.av.tr/wp-content/uploads/2019/09/Cilt-93Say\%C4\%B1-2019-4.pdf, (E.T:07.05.2021).

Williams, Damien P.: "Strange Things Happen at the One Two Point: The Implications of Autonomous Created Intelligence in Speculative Fiction Media, The Machine Question: AI, Ethics and Moral Responsibility", AISB/IACAP WORLD CONGRESS 2012, Birmingham, UK, 2-6 July 2012, s. 97-104, https://citeseerx.ist.psu.edu/viewdoc/download?doi= 10.1.1.308.8935\&rep=rep1\&type $=$ pdf, (E.T:12.09.2021).

Yılmaz, Atınç/Kaya, Umut: Derin Öğrenme, 3. Baskı, KODLAB Yayın Dağıtım, Ocak 2021.

Yılmaz, Gökhan Oğuz: "Yargı Uygulamasında Yapay Zekâ Kullanımı Yapay_Zekâ Hâkim Cübbesini Giyebilecek Mi?”, Adalet Dergisi, Sayı: 66, 2021/1, s. 379-415, https://dergipark.org.tr/tr/pub/adaletdergisi/ issue/62377/940417, (12.09.2021).

Yüksel, Bozkurt Armağan Ebru: "Robot Hukuku", Türkiye Adalet Akademisi Dergisi, Cilt: 7, Say1: 29, 2017, s. 85-112.

Zeytin, Zafer/Gençay, Eray: "Hukuk ve Yapay Zekâ: E-kişi, Mali Sorumluluk ve Bir Hukuk Uygulaması", Türk Alman Üniversitesi Hukuk Fakültesi Dergisi, Cilt: 1, Sayı: 1, 2019, s. 39-70. 
